\title{
Canadian Association of Neurosciences Review: Prion Protein and Prion Diseases: The Good and the Bad
}

\author{
Malcolm J. Gains, Andrea C. LeBlanc
}

\begin{abstract}
In the 1700's a strange new disease affecting sheep was recognized in Europe. The disease later became known as "Scrapie" and was the first of a family of similar diseases affecting a number of species that are now known as the Transmissible Spongiform Encephalopathies (TSEs). The appearance of a new disease in humans linked to the consumption of meat products from infected cattle has stimulated widespread public concern and scientific interest in the prion protein and related diseases. Nearly 300 years after the first report, these diseases still merit the descriptor "strange". This family of diseases is characterized by a unique profile of histological changes, can be transmitted as inherited or acquired diseases, as well as apparent sporadic spontaneous generation of the disease. These diseases are believed by many, to be caused by a unique protein only infectious agent. The "prion protein" $\left(\mathrm{PrP}^{\mathrm{C}}\right)$, a term first coined by Stanley Prusiner in 1982 is crucial to the development of these diseases, apparently by acting as a substrate for an abnormal disease associated form. However, aside from being critical to the pathogenesis of the disease, the function of PrPC $\mathrm{P}^{\mathrm{C}}$, which is expressed in all mammals, has defied definitive description. Several roles have been proposed on the basis of in vitro studies, however, thus far, in vivo confirmation has not been forthcoming. The biological features of $\mathrm{PrP}^{\mathrm{C}}$ also seem to be unusual. Numerous mouse models have been generated in an attempt to understand the pathogenesis of these diseases. This review summarizes the current state of histological features, the etiologic agent, the normal metabolism and the function of the prion protein, as well as the limitations of the mouse models.
\end{abstract}

RÉSUMÉ: La protéine prion et les maladies à prion : le bon et le mauvais. Au dix-huitième siècle, on s'est aperçu que les moutons étaient atteints d'une nouvelle maladie étrange en Europe. Cette maladie a plus tard été appelée « Scrapie » (la tremblante du mouton). C'était la première d'une famille de maladies similaires atteignant un certain nombre d'espèces animales qu'on désigne maintenant sous le vocable d'encéphalopathies spongiformes transmissibles (EST). L'apparition chez l'humain d'une nouvelle maladie liée à la consommation de produits carnés provenant d'animaux infectés a suscité beaucoup d'inquiétude dans la population et d'intérêt scientifique pour la protéine prion et les maladies qui y sont associées. Environ 300 ans après que les premiers cas aient été rapportés, ces maladies méritent toujours d'être décrites comme «étranges ». Cette famille de maladies est caractérisée par un profil unique de changements histologiques, elles peuvent être transmises de façon héréditaires ou être acquises et on peut observer des cas sporadiques dont la génération semble spontanée. Plusieurs croient que ces maladies sont causées par un agent infectieux de nature uniquement protéique. La «protéine prion » (PrPc), une expression utilisée pour la première fois par Stanley Prusiner en 1982, est cruciale pour le développement de ces maladies agissant, semble-t-il, comme substrat à une forme anormale de la protéine associée à la maladie. Cependant, la fonction de PrPc, une protéine qui est exprimée chez tous les mammifères, n'a pas encore pu être décrite définitivement, en dehors du fait qu'elle est cruciale dans la pathogenèse de la maladie. On a proposé plusieurs rôles pour la PrPc sur la base des études in vitro, mais aucun n'a jamais été confirmé in vivo. Les caractéristiques biologiques de la PrPc semblent également inusitées. Plusieurs modèles de souris ont été créés afin d'essayer de comprendre la pathogenèse de ces maladies. Cette revue fait le sommaire des connaissances actuelles sur les caractéristiques histologiques, l'agent étiologique, le métabolisme normal et la fonction de la protéine prion, de même que les limites des modèles chez la souris.

Can. J. Neurol. Sci. 2007; 34: 126-145

The prototypic prion disease is a naturally occurring disease of sheep and goats called "scrapie" that was first described in the literature in $1732 .{ }^{1}$ The prion diseases have since come to be known as transmissible spongiform encephalopathies (TSE) and have been reported in a large number of animal species. These other diseases include, transmissible mink encephalopathy, ${ }^{2}$ chronic wasting disease of mule deer and elk, ${ }^{3}$ bovine spongiform encephalopathy (BSE), ${ }^{4}$ and feline spongiform
From the Department of Neurology and Neurosurgery (MJG, ACL), McGill University; The Bloomfield Center for Research in Aging, Lady Davis Institute for Medical Research (ACL), Sir Mortimer B. Davis Jewish General Hospital, Montreal; Département de pathologie et microbiologie (MJG), Faculté de médecine vétérinaire, University de Montréal, St. Hyacinthe, Québec, Canada.

Received OCtober 19, 2006. AcCePted in FinAl form February 24, 2007. Reprint requests to: Andrea C. LeBlanc, The Bloomfield Center for Research in Aging, Lady Davis Institute for Medical Research, Sir Mortimer B. Davis Jewish General Hospital, 3755 Ch. Côte Ste-Catherine, Montréal, Québec, H3T 1E2, Canada. 
encephalopathy. 5 Spongiform encephalopathies have also been described in a number of zoo animals including; kudu, nyala, Arabian oryx, Scimitar horned oryx, eland, gemsbok, bison, ankole, tiger, cheetah, ocelot and puma, which have developed coincident with the emergence of BSE. ${ }^{2}$ Human prion diseases include Creutzfeldt-Jakob disease (CJD), Gerstmann-StrausslerScheinker disease (GSS), $\mathrm{Kuru}^{2}$ and fatal familial insomnia (FFI). ${ }^{6}$ In 1995, a novel human prion disease, variant CJD (vCJD) was identified and subsequently found to be caused by the same prion strain that causes BSE in cattle. ${ }^{7}$ This finding has fueled fears that dietary exposure to BSE prions may lead to a major epidemic of vCJD in the UK and other countries, ${ }^{7}$ and has understandably stimulated considerable research interest in these diseases. A similar concern is presently raised in North America with the finding of BSE in Alberta and CWD in the western provinces and mid-western states. ${ }^{8}$

Scrapie was demonstrated to be a transmissible disease by inoculation experiments in sheep and goats in $1936 .{ }^{2}$ Scrapie was initially believed to be caused by a "slow virus" infection, due to the prolonged incubation period. ${ }^{2}$ Investigation into an epidemic of a neurodegenerative disease known as Kuru, affecting members of the Fore linguistic group in the Eastern Highlands of Papua New Guinea, incriminated cannibalistic feasts in the transmission of the disease. ${ }^{9}$ Subsequently, Kuru, CJD and GSS were all successfully transmitted to chimpanzees, confirming the transmissible nature of these diseases..$^{2,10}$

\section{Classification of prion diseases}

The prion diseases are classified etiologically, as acquired, inherited and sporadic. Acquired cases have resulted from cannibalism, ${ }^{9}$ accidental exposure to infected tissues during medical or surgical procedures, such as via contaminated stereotactic electroencephalogram electrodes, ${ }^{11}$ corneal transplants, ${ }^{12}$ dura mater grafts, ${ }^{13}$ and the use of human pituitaryderived gonadotrophin. ${ }^{14}$ Dietary exposure to BSE has been responsible for an increasing number of vCJD cases, and this number may continue to increase as the incubation period is unknown. ${ }^{7}$ This was quite surprising since epidemiological studies did not provide evidence for a link between scrapie and CJD in humans. ${ }^{15}$

Approximately $15 \%$ of human cases of prion disease are inherited and associated with mutations in the prion protein gene (PRNP). ${ }^{16}$ Over 20 distinct mutations in the PRNP gene have thus far been identified..$^{17}$ These occur as missense mutations, ${ }^{18,19}$ non-sense mutations,$^{20}$ or insertions in the octapeptide repeat region..$^{21}$ The main familial forms of prion diseases are classified as $\mathrm{CJD}^{22} \mathrm{GSS}^{23} \mathrm{FFI}^{24}$ or familial atypical spongiform encephalopathy (FASE). ${ }^{25}$ Despite all being associated with a single point mutation or insertional mutation in the prion protein gene, these diseases have unique clinical profiles and different parts of the brain are affected..$^{22}$

The overwhelming majority of human prion cases, nearly $85 \%$, have no clear evidence of a genetic mutation in PRNP nor documented exposure to an infectious agent and so are termed sporadic. $^{2}$ The majority of these cases are CJD, ${ }^{26}$ although sporadic forms of $\mathrm{GSS}^{27}$ and fatal insomnia ${ }^{28}$ have been described.

\section{Clinical Features and Pathology}

Clinically Kuru and GSS cases present with ataxia, referable to the cerebellum, whereas, classical CJD presents as a rapidly progressive, multifocal dementia, usually with myoclonus. ${ }^{2}$ FFI cases present with insomnia ${ }^{24}$ and FASE cases suffer initially from memory problems. ${ }^{25}$ Variant CJD is however, dominated by behavioral and psychiatric signs. ${ }^{2}$ Scrapie in sheep is also marked in its early stages by behavioral abnormalities (i.e. withdrawal from normal flock societal behavior, nervousness, aggression) and pruritis, with progressive ataxia and trembling when excited. ${ }^{29}$

The classical triad of histopathological features of the prion diseases, spongiform vacuolation, neuronal loss and astrocytosis, are common to both animal and human diseases..$^{30}$ Amyloid plaques have also been described in some cases. ${ }^{30}$ The incubation period, type, severity and distribution of these pathological changes, when scrapie strains are inoculated into a given strain of mice, are sufficiently specific to allow the identification of approximately 20 specific strains of scrapie. ${ }^{31}$

\section{Vacuolation}

Vacuolation is found within the perikarya and within neuronal processes. ${ }^{32}$ It is a relatively common and prominent finding in both BSE and scrapie, though it is not invariably present. ${ }^{33}$ In $\mathrm{BSE}$, vacuolation is predominantly found in the paraventricular area of the hypothalamus, thalamus, periaqueductal gray matter, reticular formation, nucleus of the solitary tract, and the nucleus of the spinal tract of the trigeminal nerve. ${ }^{34}$ In pigs infected with the BSE agent, vacuolation is most prominent rostral to the medulla, in the frontal cerebral cortex, striatum, thalamus, although it can also be found in the periaqueductal gray matter, tectum, with occasional vacuoles in the cerebellum. ${ }^{35}$ The brainstem is also the area most commonly affected in sheep with scrapie, although the severity of the vacuolation varies with the breed of sheep. ${ }^{36}$ The most consistent lesions are described in the reticular formation, dorsal nucleus of the vagus, lateral cuneate nucleus, and when the spinal cord is affected, in the dorsal horn and intermediate gray matter. ${ }^{36}$ Vacuolar change is an infrequent finding in transmissible mink encephalopathy. ${ }^{32}$ Vacuolation may also be inconspicuous in cases of classical CJD. ${ }^{37}$

In murine models of scrapie, vacuolation is not prominent early in the disease process but increases rapidly in the terminal stages of the disease. ${ }^{38}$ The location of the vacuolation varies with scrapie strain in mouse models, however, the cerebellum is generally affected as a late event. ${ }^{39}$ There is however, one strain of scrapie, $22 \mathrm{~L}$, that produces significant cerebellar lesions when injected into mice. ${ }^{31}$ BSE when inoculated into mice, also produces cerebellar lesions. ${ }^{40}$

Vacuoles may also occur in oligodendrocyte cytoplasm, ${ }^{38}$ within the myelin sheath ${ }^{41}$ and in astrocytes. ${ }^{42,43}$ The vacuoles may be single membrane bound, ${ }^{44}$ double membrane bound, ${ }^{41}$ unbound ${ }^{42,43}$ or any combination of these in the same mouse model of the disease. ${ }^{38}$ Baker et $\mathrm{al}^{44}$ concluded that the single membrane bound vacuoles most likely originate in the smooth endoplasmic reticulum. Jeffrey et $\mathrm{al}^{32}$ reported that vacuoles may also originate from mitochondria, or from within processes formed by the disassembly of microtubules and neurofilaments. Liberski et $\mathrm{al}^{45}$ demonstrated that the intraocular injection of 
tumor necrosis factor produced lesions in the mouse optic nerve similar to the changes seen in the myelin sheaths of panencephalopathic type of CJD. The appearance of the vacuoles is not closely linked with clinical disease as agent replication and tissue infectivity precede vacuolation ${ }^{40,46,47}$ and nonvacuolated areas of the brain may still be infectious. ${ }^{48}$ In hamster models of scrapie, clinical signs may precede the appearance of vacuolation. ${ }^{47}$ Vacuolation is reduced in mink with the ChediakHigashi gene ${ }^{49}$ and in beige mice. ${ }^{32}$ These mutations are associated with abnormalities in membrane bound organelles, including melanosomes and lysosomes, as well as a deficiency of lysosomal enzymes. ${ }^{32}$ Vacuolation is also a feature of accelerated aging in mice $^{50}$ and has also been reported in experimental rabies infections in skunks and foxes,${ }^{51}$ as well as in retroviral infections in mice. ${ }^{52}$ Taken together, these findings suggest that the vacuolation in transmissible spongiform encephalopathies (TSEs), one of the cardinal signs of the disease, is not the result of a pathologic change in a specific organelle but rather a more general feature of degeneration within the nervous system. The variable appearance of vacuolation and its lack of specific consistent temporal relationship with infectivity or clinical signs also suggest that it is a marker of degeneration rather than the specific cause of the pathological changes or clinical signs.

\section{Neuronal loss}

Neuronal loss is considered to be part of the classical triad of features of the TSEs, however, reliable documented evidence of this change is difficult to find. In many cases of CJD and GSS neuronal loss has not been objectively assessed. ${ }^{53}$ Neuronal loss has not been unequivocally described in natural scrapie. ${ }^{53}$ It has however, been described in $\mathrm{BSE}^{54}$ and in murine scrapie. ${ }^{55}$ Several features described in CJD may suggest neuronal injury including; irregular dendrites with reduced spines, dendrites with constrictions and dilations along their processes, axonal dystrophy, frequent formation of ubiquitin protein conjugates and neuronal autophagy. ${ }^{53}$ Neurofilament proteins are often abnormally phosphorylated. ${ }^{53}$ These findings suggest that neuronal loss is not the major cause of the clinical signs noted in the TSEs, but rather indicates that cell death is the result of a pathological process during which the neuron loses its ability to perform its function. Furthermore, this suggests that the pathological process in the disease is degeneration rather than cell death or apoptosis. In the early stages, degeneration causes dysfunction of the cell and is reversible. If the cells in question are neurons, profound symptoms or clinical signs may result, although the neurons may still be present. However, if the insult that initiated the degeneration continues, the cell will reach a point where it is unable to compensate and fulfill its physiological functions and cell death or apoptosis will result. The neuronal loss described in BSE, as well as in scrapie and BSE inoculated mice, may suggest a more virulent pathogen or more susceptible host. In these cases, the time for degeneration of the neurons prior to cell death is extremely short.

\section{Astrocytosis}

Although part of the "classical triad" of TSE pathologic findings, astrocytosis is a variable but sometimes prominent feature. ${ }^{56}$ Mild astrocytosis is present in many natural cases of scrapie and in some GSS patients, though it can be severe in many cases of CJD. ${ }^{57}$ Astrocytosis is present in most neurodegenerative diseases and is one of a limited repertoire of responses to injury in the central nervous system (CNS). ${ }^{32}$ Ultrastructural and immunohistochemical features of astrocytosis include increased expression of glial fibrillary acidic protein, vimentin and the accumulation of glycogen, features that are typical of reactive cells. ${ }^{58}$ Therefore, astrocytosis is most likely a response to the degenerative process induced by the TSE agent, rather than a specific response to the TSE agent itself.

Many reports indicate that there is no significant immune response with scrapie infection. ${ }^{59}$ However, in cases with vacuolation or disease specific $\operatorname{PrP}$ accumulation, increased numbers of microglial cells have been reported ${ }^{32}$ and confirmed in mouse scrapie models. ${ }^{60}$ Scrapie infection in mice results in induction of IL- $1 \beta$ and TNF $\alpha$ in glial cells, ${ }^{60}$ as well as NF- $\mathrm{BB}$, the major transcription activator for inflammatory cytokines. ${ }^{61}$ These findings do not rule out a more subtle immune response in the CNS, perhaps mediated by activated microglia and cytokines.

\section{Amyloid plaques}

Amyloid plaques were first described in kuru and were reported most consistently in the cerebellum. ${ }^{62}$ However, they are only rarely found in scrapie and BSE, and when present, are usually present in perivascular locations. ${ }^{34}$ Immunohistochemical studies have demonstrated that these plaques contain amyloid fibrils composed of $\mathrm{PrP}^{63}$ and astrocytic and microglial processes. ${ }^{64}$ The cell processes become a more prominent component of the plaques over time. ${ }^{53}$ Ultrastructural and immunocytochemical studies have shown that PrP accumulates in astrocytic and microglial lysosomes, suggesting that these cells are involved in the phagocytosis and removal of abnormal or excess PrP, rather than in its production. ${ }^{53}$

\section{Etiologic Agent \\ Protein-only theory}

Numerous transmission studies have indicated that an infectious agent causes these diseases. The long incubation period between inoculation and the development of the disease led to the concept of a "slow virus" being the causative agent. ${ }^{2}$ Alper et $\mathrm{al}^{65}$ used the ability of ionizing radiation to inactivate biological activity, and determined that the agent may not contain nucleic acid and if it did, it must contain less than 800 bases. Subsequently, Pattison and Jones ${ }^{66}$ suggested that the agent might be associated with a small basic protein. More recently, based on titration and transmission studies, the scrapie agent has demonstrated resistance to many treatments that degrade nucleic acids. It is resistant to wide changes in $\mathrm{pH}$, nucleases, phosphodiesterases, ultraviolet irradiation at $254 \mathrm{~nm}$, divalent cation hydrolysis with $\mathrm{Zn}\left(\mathrm{NO}_{3}\right)_{2}$, photochemical inactivation with psoralens and inactivation by hydroxylamine. ${ }^{47}$ While there are viruses that are resistant to some of these procedures, there is no known virus resistant to them all. ${ }^{47}$ However, these findings do not rule out the possibility of a viruslike agent. In contrast, infectivity of the agent is reduced following treatments that denature proteins, such as; digestion with proteinase $\mathrm{K}$ or trypsin, chemical modification with 
diethylpyrocarbonate, treatment with sodium dodecyl sulfate (SDS), chaotropic salts such as guanidinium thiocyanate, phenol, and urea. ${ }^{47}$ Taken together, these observations led Stanley Prusiner to propose that the agent responsible for the TSEs was devoid of nucleic acids and was composed solely of protein, the "protein-only" hypothesis. This was clearly a unique concept. Prusiner ${ }^{47}$ introduced the term "prion" to describe the agent. The purported prion protein was subsequently isolated and found to be a sialoglycoprotein, containing a 27 to $30 \mathrm{kDa}$ core that was resistant to proteases, which became known as $\mathrm{PrP}^{27-30} \cdot{ }^{67}$ Partial amino acid sequencing and cDNA construction led to the discovery that the prion protein was encoded by a single-copy chromosomal gene rather than the DNA of an infectious agent. ${ }^{68}$ The prion protein gene (PRNP) encodes a 33-35 kDa protein $\left(\mathrm{PrP}^{\mathrm{C}}\right)$ that is sensitive to proteases. ${ }^{69}$ The $\operatorname{PrP}^{27-30}$ proteaseresistant form is known as the scrapie protein $\left(\mathrm{PrP}^{\mathrm{Sc}}\right)$ and has the same amino acid sequence as the normal cellular form $\mathrm{PrP}^{\mathrm{C}}$, from which it is derived by posttranslational modification. ${ }^{69,70}$ Comparison of $\mathrm{PrP}^{\mathrm{C}}$ and $\mathrm{PrP}^{\mathrm{Sc}}$ structure reveals that $\mathrm{PrP}^{\mathrm{C}}$ contains $42 \% \alpha$-helix and only $3 \% \quad \beta$-sheet, whereas $\mathrm{PrP}^{\mathrm{Sc}}$ contains $43 \% \quad \beta$-sheet and $30 \% \alpha$-helix. ${ }^{71}$ The protein-only hypothesis proposes that $\mathrm{PrP}^{\mathrm{Sc}}$ acts as a template to change the conformation of $\mathrm{PrP}^{\mathrm{C}}$ into the $\mathrm{PrP}^{\mathrm{Sc}}$ form and $\mathrm{PrP}^{\mathrm{Sc}}$ is inextricably linked with the disease state..$^{17,72,73}$ The theory has been modified to suggest that another protein, "Protein X" may act as a facilitator in this conversion. ${ }^{73,74}$ While the protein only theory has gained wide acceptance, the theory that the scrapie agent contains a virus-like nucleic acid is still championed by some researchers.

Resistance to UV and ionizing radiation does not prove that the scrapie agent does not contain nucleic acid, only that is must be small. ${ }^{65,75}$ Narang $^{76}$ reviewing the resistance data, states that the data does not preclude the presence of a virus and since conventional viruses depend on their protein coat for their integrity and infectivity, decreased infectivity as a result of treatments that denature proteins does not prove that nucleic acid is not present. Moreover, Narang interprets the data as being supportive of the presence of nucleic acid in the agent, as DNA is known for its tremendous stability and biologically active DNA has been amplified from fossils and tissues that have been fixed in formalin and maintained in a paraffin block for over 40 years, conditions that proteins cannot withstand. Ultrastructurally, scrapie-associated fibrils and tubulofilamentous virus-like particles (nemavirus particles, NVP) are consistently seen in TSEs. ${ }^{76}$ These are interpreted to be ultrastructural markers whereas $\mathrm{PrP}^{\mathrm{Sc}}$ is stated to be a protein marker of the agent. $^{76}$ Narang $^{76}$ argues that the protein-only hypothesis is based on negative and indirect evidence and further, that $\operatorname{PrP}$ post-translational modification is a pathological process and that $\mathrm{PrP}^{\mathrm{Sc}}$ is a by-product of the disease process rather than the agent itself. Narang ${ }^{76}$ proposes that the agent contains a nucleic acid that encodes the "protein X", the protein now believed to be required by the Prusiner group to facilitate conversion of $\mathrm{PrP}^{\mathrm{C}}$ to $\mathrm{PrP}^{\mathrm{Sc}}$. Single stranded DNA (ssDNA) of $1.2 \mathrm{~kb}$ has been purified from homogenized scrapie-infected hamster brain tissue using standard phenol/chloroform extraction and alkaline gel electrophoresis. ${ }^{77}$ This ssDNA has a multi-palindromic structure that may explain its tremendous stability. ${ }^{76}$ Narang claims that this ssDNA has been purified and injected into hamsters, and has reproduced the disease. ${ }^{76} \mathrm{He}$ suggests that the ssDNA with the help of a carrier protein transmits the disease and that incorporation of the ssDNA into host DNA could explain the familial inheritance of scrapie in sheep, as well as inherited cases of CJD and GSS. However, these results have not been independently reproduced by other researchers.

Perhaps the most serious challenge to the protein-only theory has been raised as a result of the observation that the prion from a donor species, passaged in other species and then reisolated and injected into mice, retains its original amino acid sequence and phenotypic properties, and does not acquire the amino acid sequence of the $\operatorname{PrP}^{\mathrm{C}}$ from the intervening species. ${ }^{78,79}$ Thus far, approximately 20 distinct scrapie strains have been identified via mouse inoculation tests. ${ }^{31}$ As these strains can be identified by passage through mice of a single genotype, strain variation must be specified by the agent and be independent of the host. ${ }^{31}$ These observations are difficult to reconcile with a single $\operatorname{PrP}^{\mathrm{Sc}}$. The Prusiner group argues that the different strains can be explained by different posttranslational modifications of the $\operatorname{PrP}^{C}$ and structures induced by the $\operatorname{PrP}^{\mathrm{Sc}} \cdot{ }^{17}$

\section{Toxin or metabolic disorder theory}

Another interpretation of the data by $\operatorname{Rico}^{80}$ yields an alternative theory regarding the agent. Rico argues that when considering $\mathrm{PrP}^{\mathrm{Sc}}$, one must also consider the way that water interacts with globular proteins, as water participates in the macromolecular structure of proteins. $\mathrm{PrP}^{\mathrm{Sc}}$ is strongly hydrophobic, water insoluble and surrounded by a microanhydrous environment, and probably a $1 \mathrm{~nm}$ thick gas cap, that is most likely composed of $\mathrm{CO}_{2} \cdot{ }^{80}$ Rico argues that the absence of water inhibits interaction with proteases and chemical deactivators that function in an aqueous medium, and also explains the resistance to heat and radiation. Rico suggests that $\mathrm{PrP}^{\mathrm{Sc}}$ interacts with $\mathrm{PrP}^{\mathrm{C}}$ to disrupt the post-translational modification of the protein following its endocytosis and recycling from the membrane location. Structural rigidity and hydrophobicity may also explain the absence of an immunological reaction. ${ }^{80}$ Based on these interpretations, Rico proposes that the inherited or sporadic spongiform encephalopathies should be considered as metabolic disorders and the acquired transmissible spongiform encephalopathies as intoxications. This is a conceptually different interpretation of the data that may also explain the inability to definitively detect nucleic acid in the agent.

\section{Virino or virus theory and other infectious agent theories}

The "virino" hypothesis suggests that the agent has an informational molecule, most likely ribonucleic acid (RNA), that is independent of the host, and that host derived PrP provides the protein component to protect the genetic material. ${ }^{81}$ Heat inactivation of TSE infectivity exhibits biphasic properties, and is consistent with a theory whereby the agent contains two components. ${ }^{79}$ In addition, Lasmézas et al ${ }^{40}$ reported that $55 \%$ of mice inoculated with a homogenate of BSE-infected cattle brain, exhibited clinical signs and infectivity, even with three subsequent passages, however, there was no detectable abnormal form of PrP. These results suggest that infectivity and the abnormal prion protein can be dissociated and led Lasmézas et 
$\mathrm{al}^{40}$ to suggest that there may be an infectious agent in addition to $\operatorname{PrP}$ and that this agent may be a nucleic acid. Lasmézas et $\mathrm{al}^{40}$ concluded that the abnormal prion accumulation was related to adaptation to a new host species, and that vacuolation and gliosis were linked to the abnormal protein accumulation. These transmission studies need to be replicated by other researchers in order to fully evaluate their significance. In addition, lack of sensitivity of the detection methods must be ruled out as a cause of the inability to detect abnormal prion protein in these transmission studies.

Manuelidis and Manuelidis ${ }^{82}$ inoculated hamsters with buffy coat samples from healthy human volunteers with no family history of CJD and were able to produce spongiform changes in the brain of inoculated animals. Brain samples from similar healthy humans did not produce disease in hamsters. The authors interpreted these findings as suggestive of a viremia being present in most people within circulating leukocytes, but disease only being seen in a very small number of people. ${ }^{82}$ Subsequent work using centrifugation in various solutions and treatment with guanidine hydrochloride or SDS on CJD infected brain samples led the authors to conclude that the CJD "agent" is a virus. ${ }^{83}$ Another group has apparently isolated from TSE's an unconventional bacterium from the genus Spiroplasma that lacks a cell wall, and have proposed this agent as a candidate causative pathogen for these diseases. ${ }^{84}$

Clearly, the exact nature of the scrapie agent has not been universally accepted at this point, and so one must keep an open mind.

\section{Pathogenesis}

\section{Sporadic and inherited forms of disease}

The spongiform encephalopathies are thought to be the result of the accumulation of an abnormal isoform of the cellular prion protein, $\mathrm{PrP}^{\mathrm{Sc}} .^{85}$ In the inherited diseases, the abnormal isoform accumulates as a result of an autosomal dominant genetic mutation in the PRNP gene, presumably resulting in a protein with a propensity to misfold into the abnormal isoform, however, direct experimental evidence to support this theory is lacking. ${ }^{86}$ The sporadic diseases account for the majority of the human cases of spongiform encephalopathy and are believed to be caused by a rare biochemical event that initiates the misfolding of the $\mathrm{PrP}^{\mathrm{C}}$ into the pathologic isoform. ${ }^{87}$ Proposed initiating metabolic events include misrouting to the cytoplasm, ${ }^{88}$ deamidation and ${ }^{89}$ interaction with bivalent manganese ions. ${ }^{90}$

\section{Acquired forms of disease}

Regardless of the nature of the etiologic agent of TSEs, it is transmissible between hosts. Understanding the mechanism of transmission is the first step towards understanding the pathogenesis of the disease. In cases of accidental transmission via medical or surgical procedures involving contaminated tissue, or in cases of experimental injection into the cerebrospinal fluid, direct transmission from nervous tissue to nervous tissue is obvious. However, in TSEs believed to be transmitted via the oral route, such as BSE, vCJD and transmissible mink encephalopathy, the route of neuroinvasion is less clear. ${ }^{91}$ Recent evidence suggests that after absorption from the gastrointestinal tract, the agent is carried via the systemic circulation to the spleen, where it invades mature follicular dendritic cells (FDC) of the white pulp. ${ }^{92}$ The FDCs are a prominent site of $\operatorname{PrP}^{\mathrm{SC}}$ deposition. ${ }^{93}$ Maturation of the FDCs is directed by cytokines released by B lymphocytes and so both cell types are critical for the propagation of the agent. ${ }^{92}$ In fact, depletion of FDCs prevents neuroinvasion ${ }^{94}$ and various B lymphocyte defects inhibit neuroinvasion. ${ }^{91}$ From the FDCs, the agent is believed to enter sympathetic nerves and from there, disseminate to the CNS. ${ }^{93}$ Consistent with these observations, hyperinnervation of the spleen results in significantly greater replication and neuroinvasion, whereas, denervation of the spleen delays or prevents neuroinvasion. ${ }^{93}$ Beekes et $\mathrm{al}^{95}$ have suggested that following absorption from the GI tract, neuroinvasion via the vagal nerve to the dorsal motor nucleus is another possibility.

According to the most widely accepted protein-only hypothesis of Prusiner, $\mathrm{PrP}^{\mathrm{C}}$ acts as substrate for $\mathrm{PrP}^{\mathrm{Sc}}$-mediated conversion of $\mathrm{PrP}^{\mathrm{C}}$ into $\mathrm{PrP}^{\mathrm{Sc}}$, with "Protein $\mathrm{X}$ " acting as a catalyst in the process. The requirement for a species specific protein required to facilitate the conversion of $\operatorname{PrP}^{\mathrm{C}}$ to $\operatorname{PrP}^{\mathrm{Sc}}$ was deemed necessary on the basis of studies with mice expressing either mouse $\operatorname{PrP}^{\mathrm{C}}$ alone, mouse $\operatorname{PrP}^{\mathrm{C}}$ and human $\operatorname{PrP}^{\mathrm{C}}$ and mice expressing a chimeric mouse/human PrP with or without expression of mouse $\mathrm{PrP}^{\mathrm{C}} .{ }^{74}$ The catalyst protein termed "Protein $\mathrm{X}$ " provided the best explanation for the transmission studies in these mice. ${ }^{74}$ Two models have been proposed to explain how $\operatorname{PrP}^{\mathrm{C}}$ may be converted to $\mathrm{PrP}^{\mathrm{Sc}}$. The first is the template-directed model, whereby a $\mathrm{PrP}^{\mathrm{Sc}}$ monomer would initiate the conversion, perhaps aided by protein $\mathrm{X}$. In this model, $\mathrm{PrP}^{\mathrm{Sc}}$ would be more stable than $\operatorname{PrP}^{\mathrm{C}}$, but kinetically inaccessible. ${ }^{96}$ The second model is the nucleation-seeding model. In this model, a nucleus of aggregated $\mathrm{PrP}^{\mathrm{Sc}}$ initiates polymerization and conversion of $\mathrm{PrP}^{\mathrm{C}}$, perhaps aided by protein $\mathrm{X}$. In this model, monomeric $\mathrm{PrP}^{\mathrm{Sc}}$ would be less stable than $\operatorname{PrP}^{\mathrm{C}}$, but would be stabilized upon joining the $\mathrm{PrP}^{\mathrm{Sc}}$ aggregate. ${ }^{97}$

$\mathrm{PrPC}^{\mathrm{C}}$ has been converted into a protease-resistant form by denaturation and incubation with $\operatorname{PrP}^{\mathrm{Sc}}$, however the product has not been demonstrated to be infectious. ${ }^{98}$ More recently, $\operatorname{PrP}^{\mathrm{C}}$ has been converted to a protease resistant form ( $\left.\mathrm{PrP}^{\mathrm{res}}\right)$ in vitro using the incubation of PrPres with normal brain homogenate and then subjecting the mix to repeated cycles of sonication via a protein misfolding cyclic amplification assay (PMCA). ${ }^{99}$ The in vitro generated product has demonstrated infectivity when inoculated into wild-type hamsters. ${ }^{99}$ Curiously however, the "purified" product is less infectious than the equivalent dilution of infectious crude brain extract. ${ }^{99}$ These experiments, although showing that $\mathrm{PrP}^{\mathrm{C}}$ can be converted to $\mathrm{PrP}^{\mathrm{res}}$ were done with the continued addition of normal brain homogenate and therefore do not rule out the presence of another factor in the brain homogenate that may be required for disease. In the protein-only theory, $\mathrm{PrP}^{\mathrm{C}}$ is required to provide a substrate to form the pathologic isoform $\mathrm{PrP}^{\mathrm{SC}}$, as has been demonstrated in the Prnp knockout studies. ${ }^{100}$ Reducing the amount of available $\operatorname{PrP}^{\mathrm{C}}$ via antibodies or inhibitors therefore, seems a logical therapeutic rationale, however, before such an approach should be undertaken, the physiological functions of $\operatorname{PrP}^{\mathrm{C}}$ must be thoroughly investigated.

In order to investigate the neurotoxicity of $\mathrm{PrP}^{\mathrm{Sc}}$, Brandner et $\mathrm{al}^{101,102}$ grafted brain tissue expressing $\mathrm{PrP}^{\mathrm{C}}$ into the brains of 
$\operatorname{Prnp}^{0 / 0}$ mice, which do not express $\operatorname{PrP}^{\mathrm{C}}$, then inoculated scrapie prions intracerebrally. The grafts developed severe neurodegenerative lesions as would be expected in a wild-type mouse, however, despite high levels of $\mathrm{PrP}^{\mathrm{Sc}}$ in the grafted tissue and throughout the brain, no pathological changes were found in the adjacent brain not expressing $\operatorname{PrP}^{\mathrm{C}}$. The $\mathrm{PrP}^{\mathrm{Sc}}$ isolated from these brains was demonstrated to be infectious. Brandner et al. concluded that $\mathrm{PrP}^{\mathrm{Sc}}$, by itself, is not neurotoxic. Interestingly, when they used an intraperitoneal route of infection, they were not able to demonstrate prions in the spleen and there was no sign of disease in the grafted brain tissue. ${ }^{103}$ They concluded that a $\operatorname{PrP}^{\mathrm{C}}$ expressing tissue is required to facilitate the invasion of prions into the brain. Irradiation of the bone marrow of these $\mathrm{Prnp}^{0 / 0}$ mice, followed by bone marrow grafts from wild-type mice, was able to elicit infectivity in the spleen following intraperitoneal challenge, but no disease or infectivity was found in the $\mathrm{PrP}^{0 / 0}$ brain. They concluded that transfer from the spleen to the CNS requires another tissue, most likely the peripheral nervous system. Other experiments in severe combined immunodeficiency mice, reconstituted with wild-type spleen grafts restored susceptibility to scrapie after peripheral inoculation. ${ }^{104}$ Other experiments with various models of immunodeficiency demonstrated that differentiated B lymphocytes play a crucial role in neuroinvasion, whereas, there was no requirement for $T$ lymphocytes. ${ }^{91}$ The same group demonstrated that the role of B cells seemed to be related to their role in inducing maturation of the follicular dendritic cells (FDCs), as prion immunoreactivity was localized to the FDCs and not the B cells. ${ }^{105}$ Overall, these findings suggest that components of the immune system are required for neuroinvasion of scrapie and that the FDCs are the most likely prion reservoir in the immune system.

In experimental scrapie infections of mice the first demonstrable indication of the presence of the agent is the extracellular accumulation of disease-specific $\mathrm{PrP}^{\mathrm{Sc}}$ in the hippocampus at around day 70 post-infection. ${ }^{106}$ Ultrastructural evidence of synaptic loss is present around day 84 post-infection, with axonal terminal degeneration and vacuolation occurring around day 98 post-infection. ${ }^{106}$ The synaptic disruption was also associated with the loss of dendritic spines and abnormal dendritic morphology. ${ }^{107}$ Siso et al ${ }^{108}$ found an overall decrease of proteins associated with synaptic function, such as synaptophysin, SNAP-25, syntaxin-1, $\alpha$-synuclein, and $\beta$ synuclein in scrapie-infected mice. Taken together, these data provide evidence for both pre and post-synaptic pathological changes associated with the disease, which would disrupt neuronal circuitry, perhaps leading to neuronal degeneration and eventually, apoptosis.

\section{Biological Features of the normal cellular Prion protein $\left(\mathbf{P r P}^{\mathbf{C}}\right)$ \\ $\operatorname{PrP}^{C}$ gene}

Isolation of the 27 to $30 \mathrm{kDa}$ protease resistant prion protein $\left(\mathrm{PrP}^{\mathrm{sc}}\right)$, and its partial amino acid sequencing, followed by cDNA construction, led to the discovery that the Hamster prion protein was encoded by a single-copy chromosomal gene rather than an infectious agent. ${ }^{68}$ Subsequently, Kretzschmar et al ${ }^{109}$ cloned the human PRNP gene, which is located on the short arm of chromosome 20.110 The human gene locus contains a 134 bp exon I and a 2355 bp exon II, separated by a 12,696 bp intron. ${ }^{111}$ The entire coding region is located in the second exon. ${ }^{109}$ The PRNP promoter region is typical for a housekeeping gene, with a $\mathrm{C}_{\mathrm{p}} \mathrm{G}$ island extending from -235 to $+167 \mathrm{bp}$ within intron I and lacks a canonical TATA box and an initiator element. ${ }^{112}$ Based on the sequence of the promoter, binding sites for transcription factors such as nuclear-factor interleukin 6 (NF-IL6), musclespecific factor MyoD, $\mathrm{S}_{\mathrm{p}} 1$, heat shock factor, AP-1, AP-2 are present, and many are well conserved among mammalian species. The presence of the NF-IL6 binding site may suggest that proinflammatory cytokines may play a role in $\mathrm{PrP}^{\mathrm{C}}$ expression. Using functional analysis of the promoter region, deletion of the region from -148 to -114 resulted in a $62 \%$ drop in gene expression in human neuronal (embryonic retinal) cells but not in HeLa (human uterine carcinoma) cells, suggesting that this region may be particularly important in neuronal cells.

\section{Familial mutations and polymorphism influence disease}

A number of amino acid mutations in $\mathrm{PrP}^{\mathrm{C}}$ in humans appear to influence the onset and phenotype of human inherited prion diseases..$^{17}$ Over 20 amino acid mutations are reported, most of which are proposed to destabilize the $\operatorname{PrP}^{\mathrm{C}}$ structure ${ }^{17}$ However, studies on the thermodynamic stability of some of these mutations do not support this hypothesis. ${ }^{86,113}$ Prion proteins with insertional mutations ( 3 or 5 additional octapeptide repeats) have a more exposed $\mathrm{N}$ terminal and are more susceptible to oxidative damage. ${ }^{114}$ Apetri et $\mathrm{al}^{115}$ found that increased thermodynamic stability of an intermediate form in the folding process of the prion protein (relative to the wild-type protein) is present in 7 out of 9 familial mutations examined and suspect that this may be a crucial factor in the conversion of these proteins to a disease associated form. However, the intermediate form for 2 out of the 9 (E200K and P102L) did not show this increased stability, indicating that this property is not consistent and so either its relationship to the disease state is coincidental rather than causative or there exists several mechanisms that lead to prion diseases associated with different familial prion protein mutations.

A polymorphism at position 129 has also been reported in humans, where approximately $40 \%$ of Caucasians are homozygous for methionine, $10 \%$ homozygous for valine and $50 \%$ heterozygous. ${ }^{116}$ Homozygosity at position 129 appears to predispose to sporadic CJD. ${ }^{117}$ Interestingly, all clinical cases of variant Creutzfeldt-Jakob Disease (vCJD) thus far identified, are homozygous for Met 129. ${ }^{118}$ A single preclinical case in a heterozygous Met/Val at codon 129 patient that died from a ruptured abdominal aortic aneurysm five years after receiving a blood transfusion from a patient that had subsequently developed vCJD has been identified. ${ }^{119}$ This patient had PrPres present in the spleen, but not in the central nervous system, nor was there evidence of pathological features associated with vCJD. An aspartate substitution for an asparagine at position 178 is also associated with either Fatal Familial Insomnia (FFI) or familial Creutzfeldt-Jakob Disease (fCJD), depending on whether there is a methionine or a valine at position 129 , respectively. ${ }^{19}$ Heterozygosity at codon 129 appears to delay the onset of inherited prion diseases and these data suggest that it may also be protective against vCJD. ${ }^{44,116}$ 
Predictably, other structural changes are also associated with diseases. For example, a higher number of octapeptide repeats is associated with earlier onset of disease ${ }^{7}$ characterized by dementia and ataxia. ${ }^{120}$

\section{PrP protein}

\section{Protein expression}

The $\mathrm{PrP}^{\mathrm{C}}$ protein is expressed in a wide variety of tissues including the brain, spleen, lymph nodes, kidney, pancreas, salivary gland, adrenal gland, liver, thymus..$^{90,121}$ testes, lung $^{68}$ and muscle. ${ }^{122}$ It is present in at least 27 mammalian species, birds ${ }^{123}$ and reptiles. ${ }^{124} \mathrm{~A}$ unique form of $\mathrm{PrP}^{\mathrm{C}}$, truncated at the C-terminus is expressed only in rodent, cattle and human spermatozoa. ${ }^{125}$ The expression of $\mathrm{PrP}^{\mathrm{C}}$ increases with age in mice. ${ }^{126}$ Human $\mathrm{PrP}^{\mathrm{C}}$ is a 253 amino acid precursor protein encoded from an intronless open reading frame ${ }^{127}$ and has a molecular weight of 25 to $35 \mathrm{kDa} .{ }^{128}$ The protein contains 254 amino acids in the mouse. ${ }^{111}$

Not only is $\operatorname{PrP}^{\mathrm{C}}$ ubiquitously expressed, but key elements of the protein structure are also highly conserved. The human protein has four identical proline and glycine-rich tandemly repeated octapeptides (ORs) at the N-terminus, ${ }^{120}$ a central transmembrane domain and a stop transfer effector domain (STE)..$^{70,128}$ However, the number of ORs in homozygous individuals varies among species from four in humans ${ }^{120}$ and golden mole, up to seven in the gymnure and leaf-nosed bat. ${ }^{127}$ Many motifs involved in post-translational modification of the protein (see below) are also conserved among species; glycosylation sites, the hydrophobic transmembrane domain, structural elements for $\mathrm{N}$ and $\mathrm{C}$-terminal processing and attachment of the GPI anchor to the outer cell membrane. ${ }^{127}$

\section{Post-translational modification}

$\operatorname{PrP}^{\mathrm{C}}$ is directed cotranslationally into the lumen of the endoplasmic reticulum (ER), a process that is mediated by a 22 amino acid N-terminal signal peptide (Figure 1). ${ }^{129}$ Within the $\mathrm{ER}$, the $\mathrm{N}$-terminal signal sequence is removed, as is a 23 amino acid C-terminal sequence, which facilitates the addition of the GPI anchor for attachment to the cell membrane. A disulphide bond between Cys 178 and Cys 213 is essential for proper folding of the protein. ${ }^{130}$

A particularly important post-translational modification involves N-glycosylation, which has been mapped to Asn 180 and Asn 196 in the human protein. ${ }^{131}$ High-mannose glycosylation and addition of the GPI anchor occur concurrent with or soon after translation and translocation of polypeptides into the lumen of the ER. ${ }^{132}$ The N-linked oligosaccharide chains that are added in the ER are rich in mannose and as such, are sensitive to endoglycosidase $\mathrm{H}$ digestion. ${ }^{133}$ These oligosaccharides are later modified by the addition of sialic acid in the Golgi and are resistant to digestion with endogycosidase H. Final maturation of glycosylation requires transit to the Golgi apparatus where N-acetylneuraminic acid is added to the GPI anchor. ${ }^{134}$ Caughey et al ${ }^{132}$ described three main glycoforms of the protein, fully glycosylated, monoglycosylated and unglycosylated, which can readily be identified by western blotting of protein extracts. However, given that glycosylation occurs in the $\mathrm{ER}$ as PrP is being translated, and transit to the Golgi is required to add $\mathrm{N}$-acetylneuraminic acid, these three main glycoforms could also represent mature glycosylated and immature glycosylated forms. It would therefore be advisable to check the status of PrP glycosylation with endoglycosidase $\mathrm{H}$ or $\mathrm{N}$ glycosidase $\mathrm{F}$ (PNGase F) in order to clearly understand glycosylation of PrP in various situations. Glycosylation is thought to play an important role in intracellular trafficking of the protein, ${ }^{135}$ and may also play a role in the folding or misfolding of the protein. ${ }^{136}$ Indeed, N-glycosylation is believed to help stabilize the normal structure of $\operatorname{PrP}^{\mathrm{C}} .^{137}$

Three topological forms of $\mathrm{PrP}^{\mathrm{C}}$ have been identified. ${ }^{128}$ Using cell-free translation systems containing ER-derived microsomal membranes, Hegde et $\mathrm{al}^{128}$ identified a Ctransmembrane form ( $\left.{ }^{\mathrm{Ctm}} \mathrm{PrP}\right)$ where the $\mathrm{C}$-terminal is within the ER lumen and following the normal maturation and transit of the protein through the Golgi apparatus, would be expressed on the extracellular surface, an N-transmembrane form ( $\left.{ }^{\mathrm{Ntm} P r P}\right)$, where the N-terminal is within the ER lumen and would be expressed on the extracellular surface, and a secreted form, entirely within the ER lumen, where it would be attached to the cell surface via the GPI anchor. The authors suggested that CtmPrP might be associated with disease. Hegde et al $^{128}$ also described the secreted $\operatorname{PrP}\left(\mathrm{PrP}^{\mathrm{C}}\right)$ and ${ }^{\mathrm{Ctm}} \operatorname{PrP}$ forms as being glycosylated and the ${ }^{N t m}$ PrP form as being unglycosylated.

Other post-translationally modified forms of PrP have also been described. Stahl et al ${ }^{134}$ identified six different glycoforms via a two-dimensional immunoblot technique. Using a similar technique, Pan et al $^{138}$ identified seven $\mathrm{PrP}^{\mathrm{C}}$ forms based on molecular weight alone. Each of these generated from 3 to 14 distinct spots on a gel as a result of different charges on the molecule. ${ }^{138}$ These different electrical charges could be due to different glycans, slight differences in the primary structure due to truncations or due to differences in the composition of the GPI anchor.

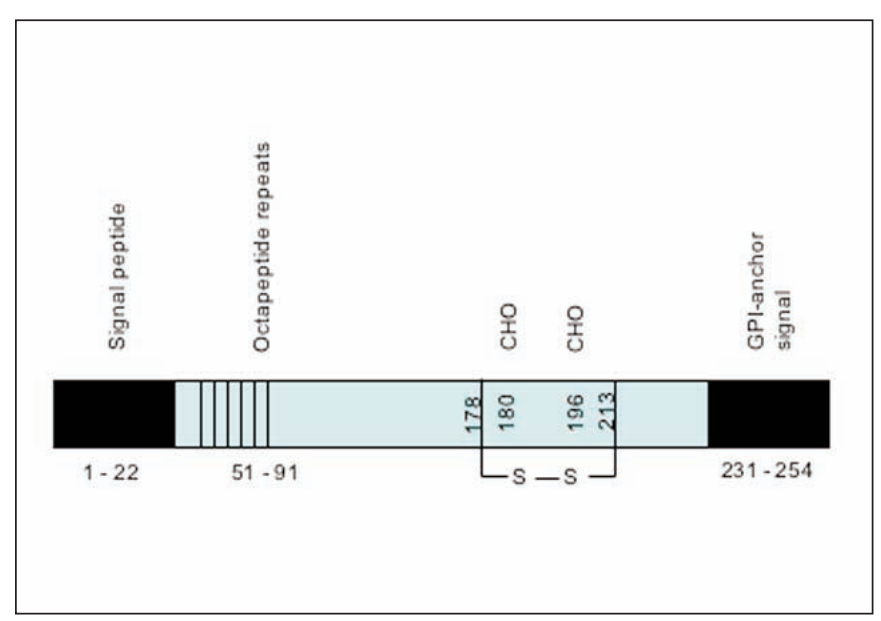

Figure 1: Schematic diagram of $\operatorname{Pr} P$ 
Clearly, there is a potential for a bewildering array of PrP forms arising from a single primary structure, due to posttranslational modification of the protein. Glycosylation in particular is thought to play an important role in the normal trafficking of $\operatorname{PrP}$ and perhaps in the relationship of $\operatorname{PrP}^{\mathrm{C}}$ to disease.

\section{Normal trafficking of PrP}

Following translation, glycosylation and the addition of the GPI anchor, in neuroblastoma lines, approximately $90 \%$ of the protein is transported to the cell surface where it is attached via the GPI anchor ${ }^{70}$ to the outer cell membrane (Figure 2). ${ }^{127}$ Also in neuroblastoma cells, the half-life on the cell surface is approximately three to six hours. ${ }^{132}$ The $\operatorname{PrP}^{\mathrm{C}}$ molecules are transported to the cell surface in association with cholesterol rafts $^{139}$ and indeed, cholesterol is required for cell surface localization. ${ }^{140}$ Rather than being simply a transport vesicle however, lipid rafts may have a role in the folding of $\operatorname{PrP}^{\mathrm{C}}{ }^{141}$

From the cell surface, some of the $\operatorname{PrP}^{\mathrm{C}}$ is internalized into an endosome, from where a C-terminal fragment may be recycled to the surface, ${ }^{142}$ however, Shyng et al ${ }^{143}$ reported that most of the protein is recycled without degradation. This endocytosis may be initiated by copper binding via the octapeptide repeats ${ }^{144,145}$ or not require copper binding. ${ }^{146}$ Internalization occurs via clathrincoated pits ${ }^{147}$ and/or caveolae-like membranous domains ${ }^{148}$ or sphingolipid/cholesterol rafts. ${ }^{146}$ The N-terminal may play a role in modulating endocytosis. ${ }^{129,146}$ Clathrin-mediated endocytosis involves the recruitment of clathrin and adaptor proteins, such as AP-2 at phosphoinositides in the membrane. ${ }^{149}$ However, impairment of clathrin-mediated endocytosis with protein mutants did not affect the internalization of the GPI anchored PrP suggesting that this mechanism may not be the major mechanism for all GPI anchored proteins. ${ }^{150}$ Shyng et al ${ }^{151}$ used hypertonic media to disrupt clathrin lattices and thereby impair endocytosis via clathrin and reported impaired $\mathrm{PrP}^{\mathrm{C}}$ internalization, suggesting that $\operatorname{PrP}^{\mathrm{C}}$ may not behave like other GPI anchored proteins. Internalization of proteins through caveolae has been suggested to divert proteins from the endosomal/lysosomal pathway. ${ }^{152}$ Nichols et al ${ }^{150}$ showed that GPI anchored proteins may use caveolae to traffic from the cell membrane to the Golgi. $\operatorname{PrP}^{\mathrm{C}}$ has been reported in endosomes containing transferrin receptors in adult mouse sensory neurons and N2a neuroblastoma cells. ${ }^{146}$ Also in neurons, $\operatorname{PrP}^{\mathrm{C}}$ has been demonstrated both in the Golgi and within cytoplasmic organelles resembling endosomes. ${ }^{153}$

Although the majority of $\mathrm{PrP}^{\mathrm{C}}$ is expressed on the cell surface, ${ }^{70,154}$ significant amounts are present within the cytoplasm of a subpopulation of neurons in the cortex, hippocampus and thalamus. ${ }^{154}$ While some of this cytoplasmic PrP may arise from endocytosed cell surface PrP, some may also represent cytosolic PrP derived from the endoplasmic reticulum associated degradative (ERAD) pathway. Indeed, several investigators have reported the accumulation of $\operatorname{PrP}$ in the cytosol of cells treated with proteasomal inhibitors ${ }^{88,155-158}$ indicating that misfolded or excess $\operatorname{PrP}^{\mathrm{C}}$ may be delivered to the cytoplasm and degraded by the proteasome system. ${ }^{157,159}$ However, because of a weak signal peptide, PrP can also be translated as a cytosolic protein after losing its signal peptide. ${ }^{160}$ Moreover, overexpression of PrP in cells often bypasses the secretory pathway to generate cytosolic PrP containing both the $\mathrm{N}$-terminal and C-terminal signal peptides. ${ }^{161} \mathrm{Ma}$ and Lindquist further reported that cytosolic PrP becomes resistant to proteinase $\mathrm{K}$ and is toxic to $\mathrm{N} 2 \mathrm{a}$ neuroblastoma cells and cerebellar granule neurons and proposed that cytosolic PrP may act as a seed for prion diseases. ${ }^{156,162}$ The proportion of $\operatorname{PrP}^{\mathrm{C}}$ that is normally present in the endolysosomal compartment ${ }^{163}$ or in the cytosol has thus far not been determined.

Taken together, these data indicate that there are several pathways by which $\mathrm{PrP}^{\mathrm{C}}$ can be recycled from the cell surface and several subcellular compartments where $\mathrm{PrP}^{\mathrm{C}}$ could be present and could conceivably interact with the disease associated form of the protein. The role of copper in the process of internalization of $\mathrm{PrP}^{\mathrm{C}}$ has also not been definitively confirmed. The seemingly conflicting results from various studies may represent differences among neoplastic cell lines, primary cell cultures, in vivo systems, as well as experimental methods to block components of the system being studied.

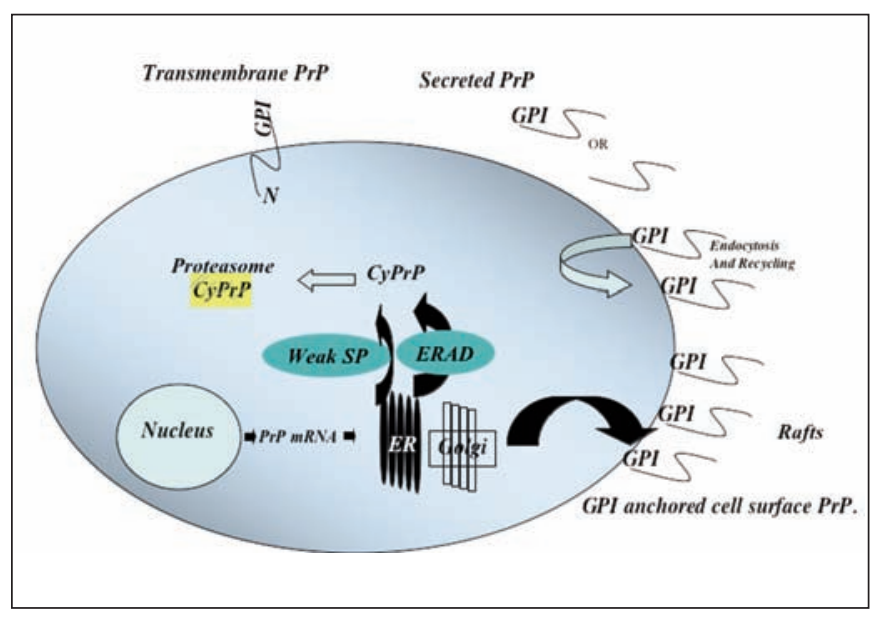

Figure 2: Schematic diagram of $\operatorname{Pr} P$ trafficking. $\operatorname{Pr} P$ is normally synthesized through the secretory pathway and acquires proper folding, $N$-linked glycosylation and a GPI-anchor in the endoplasmic reticulum. Most of this protein accumulates at the cell surface. ${ }^{250}$ Some of this cell surface protein undergoes endocytosis and can be recycled to the cell surface. ${ }^{142}$ However, mis-folded $\operatorname{PrP}$ is also known to undergo retrotranslocation into the cytosol, where it is degraded by the proteasome. ${ }^{155,157,162,251}$ In addition, the weak signal peptide of $\operatorname{PrP}$ can result in cytosolic PrP for proteasome degradation. ${ }^{160}$ In addition to the cytosolic and cell surface GPI anchored PrP, some PrP is released in the extracellular milieu and a small fraction remains as a transmembrane form although the subcellular location of this form is not known. ${ }^{248,252,253}$

\section{Proposed Physiological Functions of PrP}

The physiologic role of $\mathrm{PrP}^{\mathrm{C}}$ has been the subject of considerable debate. $\mathrm{PrP}^{\mathrm{C}}$ is attached to the outer cell surface and found throughout the cell surface ${ }^{153}$ and specifically at synaptic areas in neurons, ${ }^{164,165}$ which may suggest both a generalized 
role in cell metabolism and perhaps a specific role in synaptic transmission. $\mathrm{PrP}^{\mathrm{C}}$ is also found within the cytoplasm. ${ }^{154}$ Therefore, physiological roles for $\operatorname{PrP}^{\mathrm{C}}$ within the cytoplasm, at the cell membrane and at synapses in neurons all seem possible. The physiological roles of $\operatorname{PrP}^{\mathrm{C}}$ must be thoroughly investigated before reducing $\mathrm{PrP}^{\mathrm{C}}$ availability should be considered as a potential therapy in the prion diseases. The generation of the subtle phenotype reported in Prnp homozygous knockout mice, does not definitively rule out a role for the loss of function of $\mathrm{PrP}^{\mathrm{C}}$ in the development of the disease, as a phenotype generated by knockout procedures only demonstrates those deficits that cannot be compensated for by other systems. The post-natal knockout using the Cre-lox $\mathrm{P}$ system, knocking out PrP in neurons after nine weeks, is more convincing, ${ }^{166}$ although the loss of $\operatorname{PrP}^{\mathrm{C}}$ function simply via the loss of gene expression in mice does not test exactly the loss of $\mathrm{PrP}^{\mathrm{C}}$ function under specific stress conditions.

\section{Copper metabolism and anti-oxidant role}

Divalent copper binds to $\operatorname{PrP}^{\mathrm{C}}$ via the octapeptide repeats present in the N-terminal region. ${ }^{167}$ Two of these binding sites may be physiologically relevant with $\mathrm{Kd}$ values around $10^{-14}$ and $4 \times 10^{-14} \mathrm{M}$, which are comparable to other copper binding proteins such as superoxide dismutase and ceruloplasmin. ${ }^{168}$ However, van Rheede et $\mathrm{al}^{127}$ reported that not only do the number of octapeptide repeats vary among species, but also the number of histidine residues, which are implicated in $\mathrm{Cu}^{2+}$ binding vary, which suggests that copper binding may not be the primary function of the $\operatorname{PrP}^{\mathrm{C}}$ protein.

Copper binding to $\operatorname{PrP}^{\mathrm{C}}$ is thought to stimulate its internalization, ${ }^{144}$ perhaps via a clathrin-mediated mechanism,,${ }^{147}$ and has been proposed as the determining factor in $\operatorname{PrP}^{\mathrm{C}}$ internalization. ${ }^{169}$ Copper binding appears to be $\mathrm{pH}$ dependent, which combined with the internalization following binding, suggests a role in $\mathrm{Cu}^{2+}$ absorption. ${ }^{168} \mathrm{PrP}^{\mathrm{C}}$ has been proposed as a modulator of the activity of Copper $\left(\mathrm{Cu}^{2+}\right) / \mathrm{Zinc}\left(\mathrm{Zn}^{2+}\right)$ superoxide dismutase, a key intracellular antioxidant enzyme. ${ }^{170}$ Moreover, levels of $\mathrm{PrP}^{\mathrm{C}}$ seem to correlate with $\mathrm{Cu} / \mathrm{Zn}$ superoxide dismutase activity ${ }^{170,171}$ and glutathione reductase activity. ${ }^{171}$ However, other researchers do not find that $\operatorname{PrP}^{\mathrm{C}}$ has dismutase activity and conclude that if it has a role in the protection against oxidative stress, it is an indirect one. ${ }^{172}$

Neuronal cell cultures from Prnp ${ }^{0 / 0}$ mice are more susceptible to oxidative stress than are wild-type $\left(\mathrm{PrP}^{+/+}\right)$cells. ${ }^{173,174}$ The $\mathrm{PrP}^{0 / 0}$ neurons had significantly lower glutathione reductase activity that appeared to be modulated by $\operatorname{PrP}^{\mathrm{C}}$ expression. ${ }^{174}$ Indeed Pereira et al ${ }^{175}$ speculated that impaired brain anti-oxidant defenses may be a significant factor in the lower threshold for seizure activity noted in Prnp ${ }^{0 / 0}$ mice. In addition, spermatozoa from $\operatorname{Prnp}^{0 / 0}$ mice are more susceptible to copper toxicity than are spermatozoa expressing $\operatorname{PrP}^{\mathrm{C}}$. This suggests a protective role for copper binding by $\mathrm{PrP}^{\mathrm{C}} .{ }^{125} \mathrm{PrP}^{0 / 0}$ cell lines are also more sensitive to copper toxicity. ${ }^{165}$ Brown $^{165}$ suggested that $\operatorname{PrP}^{\mathrm{C}}$ deficient cells may be able to compensate for the lack of the protein by using other copper uptake proteins, such as copper transporting receptor proteins.

Brown, ${ }^{165}$ noting the synaptic concentration of $\mathrm{PrP}^{\mathrm{C}}$ in neurons and the copper binding affinity, proposed that $\operatorname{PrP}^{\mathrm{C}}$ has a protective role at the synapse rather than a direct role in neurotransmission. A possible anti-oxidant protective role at the synapse may be particularly significant in light of the fact that the earliest lesions in the prion diseases have been noted at the synapse. ${ }^{106-108}$

Overall, the data suggest that $\mathrm{PrP}^{\mathrm{C}}$ expression may contribute to $\mathrm{Cu}^{2+}$ binding and/or uptake, increased $\mathrm{Cu} / \mathrm{Zn}$ superoxide dismutase and glutathione reductase activity and increased resistance to oxidant stress, moreover, the loss of function of $\operatorname{PrP}^{\mathrm{C}}$ may contribute to the pathogenesis of the prion diseases. However, given that a role for $\operatorname{PrP}^{\mathrm{C}}$ in the protection against oxidative stress is not uniformly accepted, ${ }^{172} \mathrm{PrP}^{\mathrm{C}}$ may not be concentrated at the synapse ${ }^{154}$ and even that $\operatorname{PrP}^{\mathrm{C}}$ may be involved in $\mathrm{Zn}$ transport and homeostasis rather than $\mathrm{Cu},{ }^{176} \mathrm{a}$ significant role for $\mathrm{PrP}^{\mathrm{C}}$ in copper metabolism and as an antioxidant remains to be proved.

\section{Signal transduction and growth}

$\mathrm{PrP}^{\mathrm{C}}$ binds to a large number of proteins including, heat shock protein (HSP)60, ${ }^{177}$ heparin-like compounds, ${ }^{178}$ neuronal phosphoprotein synapsin $\mathrm{Ib}$, a still uncharacterized prion interactor I (PintI), ${ }^{179}$ as well as the carboxy-terminal decapeptide in the $\gamma-1$ chain of laminin, the most highly conserved of all laminin types. ${ }^{180}$ Indeed, the $37 \mathrm{kDa}$ laminin receptor protein has been proposed to act as a receptor for $\operatorname{PrP}^{\mathrm{C}}{ }^{181}$ This interaction is important for both extension and maintenance of neurites in PC12 and hippocampal neurons in culture. ${ }^{180}$ Furthermore, cultured neurons from $\operatorname{Prnp}^{0 / 0}$ mice extend fewer neurites than wild-type cultures when grown on media containing laminin, which are unaffected when exposed to anti-PrPC antibodies, a procedure that inhibits neurite growth in wild-type cultures, suggesting that those neurons that do form do not express $\mathrm{PrP}^{\mathrm{C}}$.

A fusion protein of mouse $\mathrm{PrP}^{\mathrm{C}}$ and the $\mathrm{F}_{\mathrm{C}}$ region of human $\mathrm{IgG}$ interacting with cerebellar granule neurons derived from C57BL/6 mice expressing the GPI-anchored form of mouse $\operatorname{PrP}^{\mathrm{C}}$, stimulated increased neuronal survival and neurite outgrowth compared to controls. ${ }^{182}$ Moreover, Chen et al ${ }^{182}$ also found that different members of the Src kinase family were involved in prion-mediated neurite outgrowth and neuron survival. More recently, Steele et $\mathrm{al}^{183}$ found that neuronal differentiation is delayed in vitro and in vivo if $\mathrm{PrP}^{\mathrm{C}}$ is absent and suggest that $\mathrm{PrP}^{\mathrm{C}}$ may be a positive regulator of neuronal precursor proliferation.

$\mathrm{PrP}^{\mathrm{C}}$ is also reported to play a role in known cell-signaling pathways. $\operatorname{PrP}^{\mathrm{C}}$ binds to the adaptor protein (growth factor receptor binding protein) Grb2, which is involved in activating ERK1/2 and MAP kinases. ${ }^{179}$ In a murine 1 C11 neuronal differentiation model, $\operatorname{PrP}^{\mathrm{C}}$ activates the Src family member tyrosine kinase Fyn via a caveolin-1-dependent mechanism, suggesting a role in signal transduction. ${ }^{184} \mathrm{PrP}^{\mathrm{C}}$ activation of the cAMP/PKA pathway is neuroprotective. ${ }^{185}$ The outcome of ERK-mediated or Fyn-mediated signaling is currently unknown. Zanata et al ${ }^{186}$ speculated that STI1 may be the protein that binds to $\mathrm{PrP}^{\mathrm{C}}$ and facilitates its conversion to the disease-associated form and may therefore be the "protein X" of Prusiner's proteinonly theory. ${ }^{74}$

Overall, these data indicate that $\mathrm{PrP}^{\mathrm{C}}$ is capable of binding to a variety of ligands and may potentially be involved in regulating a variety of signal transduction pathways, which affect cell 
growth and differentiation. Conclusive evidence for such a role for $\mathrm{PrP}^{\mathrm{C}}$ has not thus far been elucidated, but this appears to be a very active area of research. The expression of $\mathrm{PrP}^{\mathrm{C}}$ in a wide variety of tissues may indicate that $\operatorname{PrP}^{\mathrm{C}}$ is performing a similar role in other tissues by transmitting signals from the extracellular compartment to the intracellular milieu.

\section{Homeostatic functions}

\section{Calcium metabolism and regulating neuronal activity}

Observations made on $\mathrm{PrP}^{0 / 0}$ mice suggest that $\mathrm{PrP}^{\mathrm{C}}$ may be involved in regulating circadian rhythms and sleep patterns, ${ }^{187}$ as well as memory retention in aging rodents. ${ }^{188} \mathrm{PrP}^{0 / 0}$ mice are also known to have a lower threshold for seizure activity than their wild-type counterparts, which is believed to be related to an increased susceptibility to oxidative stress. ${ }^{175,189}$ Recently, it has been proposed that PrP may play a role in the formation of longterm memory in humans. ${ }^{190}$

Evaluation of these observations at the electrophysiological level has implicated the regulation of calcium in their pathogenesis. In hippocampal slices from $\mathrm{PrP}^{0 / 0}$ mice, $\mathrm{Ca}^{2+}$ activated $\mathrm{K}^{+}$currents are disrupted. ${ }^{191}$ These channels are involved in late after hyperpolarizations and therefore may be important in long-term potentiation and memory consolidation, and may also have a role in the lower threshold for seizures reported in $\mathrm{PrP}^{0 / 0}$ mice. Similarly, Herms et al ${ }^{192}$ examined cerebellar granule cells and found alterations in both the basal $\mathrm{Ca}^{2+}$ concentration and the changes in $\mathrm{Ca}^{2+}$ concentration with $\mathrm{K}^{+}$depolarization in tissue slices from $\mathrm{PrP}^{0 / 0}$ mice. Herms et $\mathrm{al}^{193}$ examined Purkinje cells in cerebellar slices and found a correlation between $\mathrm{PrP}^{\mathrm{C}}$ expression level and the amplitude of maximum calcium concentration after depolarization. It has therefore been proposed that PrP may play a role in regulating synaptic activity. ${ }^{166,194}$

However, another group has disputed this proposed role as they have failed to find the same electrophysiological abnormalities. ${ }^{195}$ In addition, $\operatorname{PrP}^{\mathrm{C}}$ does not appear to be concentrated at the synapse, as was previously thought. ${ }^{154}$ Moreover, most of the electrophysiological abnormalities have been reported in the hippocampus, which is not involved in the "retention" of memory. Other neurobehavioral studies in mice have suggested subtle differences between $\mathrm{PrP}^{0 / 0}$ and $\mathrm{PrP}^{+/+}$ mice, ${ }^{196}$ however, no attempt was made to interpret the findings and identify the location of any possible lesion. Given the inconsistency or purely descriptive neurobehavioral studies, the significance of these findings must be questioned. Overall these data suggest that $\operatorname{PrP}^{\mathrm{C}}$ may have a role in regulating neuronal activity, perhaps via $\mathrm{Ca}^{2+}$ gated $\mathrm{K}^{+}$channels, but this proposal requires further study.

Also related to $\mathrm{Ca}^{2+}$ metabolism, Kristensson et al ${ }^{197}$ infected mouse neuroblastoma cells with $\mathrm{PrP}^{\mathrm{Sc}}$ and noted a disruption of mitogen-activated increases in intracellular calcium concentration. The authors interpreted these findings to suggest that $\mathrm{PrP}^{\mathrm{C}}$ may be involved in regulating intracellular $\mathrm{Ca}^{2+}$ concentration. However, following $\mathrm{PrP}^{\mathrm{Sc}}$ infection, neuroblastoma cells may undergo the process of degeneration and degenerating cells would not be expected to be "normal" with respect to their physiological processes. In other words, these findings could be the effect of the degeneration rather than the cause.

\section{Nucleic acid binding}

PrP also binds to nucleic acids and induces the production of large nucleoprotein complexes when mixed with viral nucleic acids in vitro. ${ }^{198}$ Human or ovine $\operatorname{PrP}^{\mathrm{C}}$ is able to functionally replace HIV-1 nucleocapsid protein NCP7 nucleic acid chaperoning during the retroviral life cycle. NCP7 is required for the initiation of reverse transcription. ${ }^{199}$ An anti-retroviral role for $\operatorname{PrP}^{\mathrm{C}}$ has therefore been proposed. ${ }^{200}$

However, $\operatorname{PrP}^{\mathrm{C}}$ binding to nucleic acids may also have a negative side. Human recombinant $\operatorname{PrP}^{\mathrm{C}}$ binds to synthetic small highly structured RNAs under in vitro though, physiological conditions. ${ }^{201}$ The $\mathrm{PrP}^{\mathrm{C}}$ then becomes resistant to digestion by proteinase $\mathrm{K}$ and the RNA in the nucleoprotein complexes becomes resistant to digestion by ribonuclease A. Moreover, Deleault et $\mathrm{al}^{202}$ found that the addition of mammalian RNA species to normal brain homogenate seeded with prion-infected brain homogenate amplified the conversion of $\mathrm{PrP}^{\mathrm{C}}$ to $\mathrm{PrP}^{\mathrm{res}}$, a form of PrP that may be associated with disease. This amplification was inhibited by the addition of RNase in a dosedependent manner.

Taken together these findings may suggest that $\operatorname{PrP}^{\mathrm{C}}$ could play a protective role against retroviral replication in the cell, but could also be a key element in the amplification of the diseaseassociated form of PrP. Clearly, considerably more research will be required to confirm the validity of these experimental results.

\section{Involvement in the immune response}

In addition to being abundantly expressed in the brain, $\operatorname{PrP}^{\mathrm{C}}$ is also expressed in cells of the immune system. ${ }^{121}$ Treatment with the $\mathrm{T}$ lymphocyte mitogen concanavalin $\mathrm{A}$ induced significantly greater proliferation in $\mathrm{T}$ cells from $\mathrm{PrP}^{+/+}$mice compared to $\mathrm{PrP}^{0 / 0}$ mice. ${ }^{203}$ Concanavalin $\mathrm{A}$ treatment also resulted in greater production of interferon (IFN)- $\gamma$ and interleukin (IL)-2 in splenocytes from $\mathrm{PrP}^{+/+}$mice or splenocytes from $\mathrm{PrP}^{0 / 0}$ mice that had been transfected with a $\mathrm{PrP}$ expressing plasmid than splenocytes from $\mathrm{PrP}^{0 / 0}$ mice. ${ }^{204}$ These two cytokines are critical in the type 1 immune response. Treatment with anti- $\mathrm{PrP}^{\mathrm{C}}$ suppressed mitogen-induced lymphocyte activation. ${ }^{205}$

The culture of $\mathrm{CD}_{14}{ }^{+}$monocytes in the presence of IFN- $\gamma$ resulted in increased expression of $\mathrm{PrP}^{\mathrm{C}},{ }^{206}$ suggesting that $\mathrm{PrP}^{\mathrm{C}}$ may be related to increased activation of monocyte/macrophage cells. In contrast however, de Almeida et $\mathrm{al}^{207}$ found that macrophages not expressing $\operatorname{PrP}^{\mathrm{C}}$ were more efficient at phagocytosis using an in vivo peritonitis model than $\operatorname{PrP}^{\mathrm{C}}$ expressing macrophages and concluded that $\mathrm{PrP}^{\mathrm{C}}$ is a negative regulator of phagocytosis.

Expression of $\mathrm{PrP}^{\mathrm{C}}$ was down-regulated upon differentiation of hematopoietic cells along the granulocyte lineage. ${ }^{208}$ Zhang et $\mathrm{al}^{209}$ also examined $\mathrm{PrP}^{\mathrm{C}}$ expression in hematopoietic cells and found that $\mathrm{PrP}^{\mathrm{C}}$ expression in stem cells is important in their self-renewal following serial transplantation, however, they found no differences in progenitor cell or terminally differentiated hematopoietic cell numbers in $\mathrm{PrP}^{+/+}$or $\mathrm{PrP}^{0 / 0}$ mice in vivo. These findings suggest that the lack of $\mathrm{PrP}^{\mathrm{C}}$ expression is overcome in $\mathrm{PrP}^{0 / 0}$ mice, or perhaps defects may only be seen in aged mice. Alternatively, $\operatorname{PrP}^{\mathrm{C}}$ expression may be important in the experimental paradigm but less so in vivo. 
Taken together, these data suggest that $\mathrm{PrP}^{\mathrm{C}}$ may play an important role in the regulation of the type 1 adaptive immune response, a response that is obviously critical to survival of the organism. However, evidence for a role in the innate immune response or in hematopoietic differentiation and proliferation is inconsistent and no firm conclusions can be made at this time.

\section{Cell survival}

It is generally accepted that the disease-associated form of the prion protein has either a direct or an indirect role in the neurodegeneration culminating in neuronal death that is a feature of the transmissible spongiform encephalopathies. It is therefore, somewhat ironic that the normal form of the protein $\mathrm{PrP}^{\mathrm{C}}$ may be associated with neuronal survival, however there is increasing evidence that this may be the case.

Using a model for traumatic brain injury, Hoshino et $\mathrm{al}^{210}$ reported that $\mathrm{PrP}^{0 / 0}$ mice had a significantly larger lesion volume than did $\mathrm{PrP}^{+/+}$mice and also that the breakdown in the blood brain barrier in $\operatorname{PrP}^{0 / 0}$ mice was more extensive one month after the event. Similarly, in rodent models of cerebral ischemia, the ischemic penumbra was larger in $\mathrm{PrP}^{0 / 0}$ mice than $\mathrm{PrP}^{+/+}$mice..$^{211}$ In the early phase following either ischemic injury ${ }^{211,212}$ or traumatic brain injury ${ }^{213} \mathrm{PrP}^{\mathrm{C}}$ was markedly upregulated. In addition, Spudich et $\mathrm{al}^{214}$ reported larger infarcts in $\mathrm{PrP}^{0 / 0}$ mice than in $\mathrm{PrP}^{+/+}$controls and also found increased activities of ERK1/2, STAT-1 and caspase 3 in the $\operatorname{PrP}^{0 / 0}$ ischemic brains, suggesting a possible signaling mechanism through $\operatorname{PrP}^{\mathrm{C}}$ that may provide neuroprotection. In an in vivo model involving the injection of anti-PrP antibodies into the hippocampus, massive neuronal apoptosis was noted 24 hours after treatment. ${ }^{215}$ This may suggest that $\mathrm{PrP}^{\mathrm{C}}$ is involved in transmitting survival or anti-apoptotic signals into the neuron.

These findings suggest that $\operatorname{PrP}^{\mathrm{C}}$ may provide a neuroprotective role in vivo and may be particularly important in the early period after the ischemic or traumatic event. The promoter region of PrP contains binding sites for heat shock transcription factors, ${ }^{112,216}$ which could therefore provide another possible mechanism for upregulation due to cell stress and subsequent neuroprotection.

Neuroprotection could also be related to protection against oxidative stress or related to apoptosis via an anti-Bax function. Kuwahara et $\mathrm{al}^{217}$ found that $\mathrm{PrP}^{+/+}$hippocampal cell lines survive serum-deprivation induced apoptosis better than $\mathrm{PrP}^{-/-}$ cell lines. Similarly, neuronal cultures derived from $\mathrm{PrP}^{0 / 0}$ mice were more susceptible to apoptosis induced by serum deprivation than $\mathrm{PrP}^{+/+}$neuronal cultures, an effect that was abrogated by the reintroduction of $\operatorname{PrP}$ to the $\operatorname{PrP}^{0 / 0}$ neurons. ${ }^{218}$ Moreover, Kurschner and Morgan ${ }^{219}$ demonstrated that $\operatorname{PrP}^{\mathrm{C}}$ interacts with the C-terminal 37 amino acids of Bcl-2 by using a yeast two-hybrid system. However, the interaction between Bcl2 and PrP could not be confirmed in a mammalian system. They suggested that Bcl-2 may be the "protein X" presumed to be involved in converting $\mathrm{PrP}^{\mathrm{C}}$ to $\mathrm{PrP}^{\mathrm{Sc}}$ in Prusiner's protein-only theory. $^{74}$

Consistent with the anti-apoptotic function of PrP in mouse neuronal cells, Bounhar et $\mathrm{al}^{220}$ found that $\mathrm{PrP}^{\mathrm{C}}$ protects human neuronal cells in culture from Bax-mediated cell death. Furthermore, the cytosolic form of $\mathrm{PrP}^{\mathrm{C}}$ prevents Bax-mediated death in human primary neurons. ${ }^{155}$ Specifically, PrP inhibits the proapoptotic conformational change of Bax, which is an early event in the initiation of apoptosis. ${ }^{221}$ However, in Saccharomyces cerevisiae prion protein does not require other Bcl-2 family proteins to protect against Bax-mediated cell death. ${ }^{222,223}$ Further investigation by Chen et al ${ }^{182}$ revealed that the mouse $\mathrm{PrP}^{\mathrm{C}}$-human $\mathrm{IgGF}_{\mathrm{c}}$ fusion protein that resulted in increased cerebellar granule cell neurite survival also increased antiapoptotic Bcl-2 levels and decreased proapoptotic Bax levels, suggesting that $\operatorname{PrP}^{\mathrm{C}}$ may be influencing neurite survival via a Bcl-2 family mediated mechanism. In addition, $\operatorname{PrP}^{\mathrm{C}}$ overexpression in a human breast carcinoma cell line (MCF-7) induced resistance to tumor necrosis factor (TNF)- $\alpha$-induced cell death. ${ }^{224}$ Overall, these data suggest that $\mathrm{PrP}^{\mathrm{C}}$ may be influencing neuronal survival by inhibiting Bax activation, however, the exact mechanism by which PrP inhibits Bax remains to be elucidated. Furthermore, anti-PrPC antibodies inducing cross linking of $\mathrm{PrP}^{\mathrm{C}}$ molecules triggered apoptosis of hippocampal neurons in vivo. ${ }^{215}$ Whether this apoptosis is the result of the loss of a cell survival signal from $\operatorname{PrP}^{C}$ or the transmission of a cell death signal was not evaluated.

\section{Mouse Models to understand the function of $\operatorname{PrP}$ and its involvement in prion diseases}

Several mouse models of PrP have been developed over the years and have helped further understand the function of PrP in vivo. These are discussed below and summarized in the Table.

\section{$\operatorname{PrP}^{C}$ knockout mice $\left(\operatorname{PrP}^{0 / 0}\right)$}

Prusiner ${ }^{47}$ proposed that the agent responsible for the transmissible spongiform encephalopathies was devoid of nucleic acid and composed only of protein $\left(\mathrm{PrP}^{\mathrm{Sc}}\right)$. This was based largely on the resistance of the agent to numerous treatments that destroy nucleic acid, the small size constraints imposed on the agent, the inability to demonstrate nucleic acid, and the reduced infectivity induced by treatments that degrade proteins. ${ }^{47}$ In an attempt to find more conclusive evidence to support their theory, Bueler et $\mathrm{al}^{225}$ succeeded in disrupting one mouse Prnp allele of murine embryonic stem cells by homologous recombination with a 4.8-kilobase DNA fragment in which codons 4 to 187 of the 254-codon open reading frame were replaced by a neomycin phosphotransferase (neo) gene under the control of the Herpes simplex virus thymidine kinase (HSV TK) promoter. Blastocysts from C57BL/6J mice were injected with the clone and implanted into foster mothers. ${ }^{225}$ The resulting offspring were screened with polymerase chain reaction (PCR) and Southern analysis to confirm the presence of the disrupted gene and these heterozygotes mated to generate homozygous Prnp ${ }^{0 / 0}$ knockout mice. ${ }^{225}$ The genotype of these mice was also confirmed by PCR and Southern analysis. ${ }^{225}$ Manson et $\mathrm{al}^{226}$ also produced a disruption of the gene. Both groups found that, contrary to expectation, the mice survived and developed normally. ${ }^{225,226}$ These homozygous null mice (Prnp ${ }^{0 / 0}$ ) did not develop spongiform encephalopathy after inoculation with $\mathrm{PrP}^{\mathrm{Sc}}$, and did not demonstrate infectivity. ${ }^{100}$ These findings were consistent with the protein-only hypothesis, and demonstrate that $\mathrm{PrP}^{\mathrm{C}}$ is crucial to the development of and transmission of the disease, but do not prove that $\operatorname{PrP}^{\mathrm{Sc}}$ is the actual agent. Interestingly, mice heterozygous for the Prnp 
knockout expressing reduced levels of $\mathrm{PrP}^{\mathrm{C}}$ developed disease, but had prolonged incubation times. ${ }^{227}$

$\operatorname{Prnp}^{0 / 0}$ mice are reported to have altered circadian rhythms and sleep patterns. ${ }^{187}$ They may also have impaired memory retention with aging. ${ }^{188}$ Abnormal synaptic activity involving gamma aminobutyric acid $\left(\mathrm{GABA}_{\mathrm{A}}\right)$ type $\mathrm{A}$ receptors in the $\mathrm{CA} 1$ region of the hippocampus was reported by Collinge et al, ${ }^{194}$ although no effects on synaptic function were found by Lledo et al. ${ }^{195}$ Significant reductions in afterhyperpolarizations (AFPs) in hippocampal CA1 cells were also reported in a post-natal knockout of prion protein targeted to neurons in the adult mouse, suggesting a role for $\mathrm{PrP}^{\mathrm{C}}$ in regulating neuronal excitability. ${ }^{166}$ Clearly, there is no consensus at this time, regarding the effect of $\mathrm{PrP}^{\mathrm{C}}$ on synaptic activity.

$\mathrm{Prnp}^{0 / 0}$ mice are also reported to have demyelination in the peripheral nervous system, although no clinical signs have been noted in the Zurich strain developed by Bueler's group. ${ }^{228}$ The clinical signs described in other knockout strains and not in the Zurich strain, are believed to be related to variable disruption of the gene in different strains. ${ }^{228}$

Cells from Prnp ${ }^{0 / 0}$ mice also have alterations in superoxide dismutase activity (SOD-1) and therefore increased susceptibility to oxidative stress ${ }^{173}$ and defects in copper metabolism. ${ }^{167} \mathrm{Prnp}^{0 / 0}$ mice are more susceptible to seizures than their wild-type counterparts, which is also thought to be related to increased susceptibility to oxidative stress. ${ }^{189}$ Brown et al ${ }^{229}$ examined numerous biochemical parameters and found increased activity of nuclear factor NF- $\mathrm{KB}$, increased activity of manganese superoxide dismutase, perhaps in response to decreased p53, as well as decreased $\mathrm{Cu} / \mathrm{Zn}$ superoxide dismutase activity. They concluded that $\mathrm{Prnp}^{0 / 0}$ mice, or cells derived from them, have increased neuronal sensitivity to oxidative stress.

Another Prnp knockout generated by Sakaguchi et $\mathrm{al}^{230}$ led to the overexpression of a gene downstream from the Prnp gene, a $\mathrm{PrP}^{\mathrm{C}}$-like protein called Doppel $(\mathrm{Dpl})$, and progressive ataxia and cerebellar Purkinje cell degeneration by 70 weeks of age. ${ }^{231}$ This phenotype is rescued by the coexpression of $\operatorname{PrP}^{\mathrm{C}} .^{232}$ Purkinje cell degeneration is not a feature of the transmissible spongiform encephalopathies (TSEs) in mice, suggesting that this Doppel-induced disease is a distinct entity and unrelated to the TSEs. Interestingly, an N-terminally truncated form of PrP, similar to Doppel, when targeted to Purkinje cells, also leads to Purkinje cell loss and is also rescued by the reintroduction of $\operatorname{PrP}^{\mathrm{C}} .233$

\section{$\operatorname{PrP}^{c}$ Overexpressor mice $\left(\operatorname{PrP}^{\text {Oexp }}\right)$}

In order to assess the species specificity of scrapie infectivity, Scott et $\mathrm{al}^{234}$ and Prusiner et $\mathrm{al}^{235}$ constructed mice expressing Syrian Hamster prion protein $\left(\mathrm{SHaPrP}^{\mathrm{C}}\right)$, as well as endogenous mouse prion protein $\left(\mathrm{PrP}^{\mathrm{C}}\right)$. Eggs were obtained from superovulated (C57BL/6 X SJL)F1/J hybrid females mated to (C57BL/6 X SJL)F1/J hybrid males. DNA constructs were made by fusing sequences of the SHaPrP promoter, a fragment of a cDNA clone encoding the open reading frame and a restriction fragment containing the SHaPrP polyadenylation signal. ${ }^{234,235}$ The DNA constructs were microinjected into the pronuclei of one-celled mouse eggs. Weanling animals were screened for the presence of the SHaPrnp gene using Southern transfer analysis.

Mice expressing hamster $\operatorname{PrP}^{\mathrm{C}}$, in addition to mouse $\operatorname{PrP}^{\mathrm{C}}$, became susceptible to infection with Syrian Hamster prions, to which they are normally resistant, ${ }^{234}$ and the incubation time paralleled protein expression level. ${ }^{235}$ When infected with mouse prions, they had a longer incubation time than non-transgenic littermates. ${ }^{234}$ The importance of the amount of $\mathrm{PrP}^{\mathrm{C}}$ in the cell to the development of the disease was illustrated by the observation that transgenic mice overexpressing wild-type PrP, when infected with mouse prions, had a shorter incubation time. $^{236}$

These findings support a direct protein-protein interaction in the propagation of the disease. Unlike their $\operatorname{PrP}^{\mathrm{C}}$ knockout counterparts, mice expressing wild-type $\mathrm{PrP}^{\mathrm{C}}$ derived from either hamsters or sheep developed spontaneous disease, in proportion to the copy number of the transgene. ${ }^{237}$ The pathological changes described included necrotizing myopathy, demyelinating neuropathy and focal spongiform degeneration in the central nervous system (CNS). ${ }^{237}$ Cell death via overexpression of $\operatorname{PrP}$ is also demonstrated by Paitel et $\mathrm{al}^{238}$ where stably transfected cell lines overexpressing $\mathrm{PrP}^{\mathrm{C}}$ rendered cell lines more sensitive to caspase-3-mediated apoptosis.

These data indicate that the host $\mathrm{PrPC}^{\mathrm{C}}$ is qualitatively and quantitatively essential for the development of the disease.

\section{Other transgenic mice}

Thus far, approximately 20 distinct mutations in the PRNP gene have been identified. ${ }^{17}$ Partly due to the "species barrier" (i.e. difficulty in transmission of a TSE agent to a new species with a different PrP primary structure on first passage) and partly due to few studies attempting transmission, which may be a reflection of the rarity of clinical cases and therefore infectious material, brain homogenate from few of these familial mutations have successfully transmitted disease to mice. Brain homogenate from familial mutations such as E200K, M232R, P102L and D178N have successfully induced disease in mice, with variable degrees of difficulty. ${ }^{239}$

In the case of the human mutation P102L, the equivalent mouse mutation $(\mathrm{P} 101 \mathrm{~L})$ has been created in transgenic mice expressing approximately eight fold normal amounts of PrP and these mice spontaneously developed neurological "symptoms" of ataxia, lethargy and rigidity. ${ }^{240}$ Histologically, spongiform degeneration was identified in most gray and white matter structures in the cerebral hemispheres and brainstem with mild to moderate reactive astrocytic gliosis. Using $10 \%$ brain homogenate, this disease was successfully transmitted to a transgenic line expressing the same mutation at an estimated 2 fold normal levels of PrP. However, it was not transmissible to wild-type mice, even though brain extracts from human patients with the P102L mutation and human prion primary structure is transmissible to wild-type mice with the mouse primary prion structure. ${ }^{239}$

Similarly, in an attempt to reproduce the human familial A117V mutation, Hegde et al ${ }^{128}$ created a transgenic mouse predominantly expressing a $\mathrm{C}$ transmembrane form of the prion protein, ${ }^{\mathrm{Ctm} P r P}$, with Ala to Val substitutions at positions 113, 115, and 118 (PrP AV3). They were unable to demonstrate the presence of $\mathrm{PrP}^{\mathrm{Sc}}$ in the mice, however, these mice still developed neurological disease characterized clinically by ataxia and paresis. They described focal vacuolar degeneration in the neuropil of the gray matter, which was most pronounced in the 
hippocampus and piriform cortex, however, lesions in these locations do not explain the clinical signs. Hegde et al ${ }^{128}$ reported that increased ${ }^{\mathrm{Ctm}} \mathrm{PrP}$ was noted in the single GSS brain with codon 117 mutation relative to the single control brain that they examined. However, patients with this mutation predominantly present with dementia and Parkinsonian signs, with ataxia described as a minor feature. ${ }^{6}$ Histologically, these GSS patients have numerous amyloid plaques, occasional neurofibrillary tangles with variable vacuolation, gliosis and neuronal loss. ${ }^{6}$ These data suggest that the transgenic overexpression of ${ }^{\mathrm{Ctm}} \mathrm{PrP}$ may be associated with neurological disease in mice, however, the evidence for a link between ${ }^{\mathrm{Ctm}} \mathrm{PrP}$ and codon 117 mutation GSS is less convincing.

Mutations within the Prnp gene, coding for a truncated amino terminal, were reintroduced into Prnp ${ }^{0 / 0}$ mice, and resulted in granule cell loss in the cerebellum and subsequent ataxia, a phenotype that was rescued by the reintroduction of a single copy of the Prnp gene. ${ }^{241}$ Granule cell loss is not a feature of TSEs in mice, suggesting that this truncated amino terminal form of the protein is not significant in the development of the TSEs in mice. Shmerling et $\mathrm{al}^{241}$ speculated that these truncated PrPs may have competed with some other molecule for a ligand and disrupted the ligand's function.

$\mathrm{Ma}$ et $\mathrm{al}^{162}$ also created a transgenic mouse expressing cytosolic $\operatorname{PrP}\left(\mathrm{PrP}^{\mathrm{C}}\right.$ lacking both the N-terminal and C-terminal signal peptides). These mice were ataxic and had cerebellar atrophy due to massive granule cell loss. Apparently, the transgene lacked the necessary enhancer element to be expressed in Purkinje cells, and so no changes were detected in these cells. Ma et $a^{162}$ proposed a unifying model for the pathogenesis of the prion diseases, suggesting that mutations and presumably the infectious agents, increase misfolding of $\mathrm{PrP}^{\mathrm{C}}$ triggering the cell to transport these proteins to the cytosol, where they are metabolized by the proteasome. They proposed that impaired proteasomal function could provide a mechanism for the buildup of prion proteins in the cytoplasm. Similarly, Cohen and Taraboulos ${ }^{242}$ treated cells with cyclosporin A to inhibit peptidylpropyl cis-trans isomerases (PPIases) and detected the accumulation of a protease-resistant "prion-like" PrP species, which was not degraded by the proteasome and accumulated in nonmembrane bound aggresomes. Cohen and Taraboulos ${ }^{242}$ however, did not report cell degeneration or death as a consequence of their treatment. Ma et $\mathrm{al}^{162}$ found that "very small quantities of soluble PrP are toxic". Their construct induced cell death, presumably by apoptosis, as there was no inflammation described. However, neuronal loss has not been unequivocally described in scrapie, and may not be present in cases of CJD and GSS. ${ }^{53}$ Granule cell loss is not a feature of scrapie in mice, in fact, of the approximately 20 distinct scrapie strains recognized in mice inoculation tests, only $22 \mathrm{~L}$ has significant cerebellar lesions, and these consist of vacuolation of the gray matter. ${ }^{31}$ The only other mouse model of TSE that produces significant cerebellar lesions is BSE, where Purkinje cell loss, rather than granule cell loss has been described. ${ }^{40}$ The unifying process in the spongiform encephalopathies is the loss of the ability of neurons to maintain their specialized function with cell death occurring some time later i.e. degeneration, and so a proposed process that kills neurons when very small quantities of PrP are in the cytosol rather than simply impairing their function would not explain the observed sequence of lesions in the spongiform encephalopathies. For the cytoplasmic $\operatorname{PrP}$ theory of Ma et $\mathrm{al}^{162}$ to be valid in the naturally occurring diseases, the accumulated PrP isoform would have to impair neuronal function rather than simply initiate the cell death pathway. In this respect, both the pathogenesis of the disease and the lesions described by $\mathrm{Ma}$ et al, ${ }^{162}$ appear to be unique, suggesting that it is a unique disease and not part of the TSE spectrum. Moreover, Drisaldi et $\mathrm{al}^{161}$ in contrast to Ma et al ${ }^{162}$ found that blocking the proteasome in cell cultures does not result in retrotranslocation and increased PrP in the cytoplasm. Drisaldi et al $^{161}$ suggested that the neurotoxicity noted by Ma et $\mathrm{al}^{162}$ was the result of increased PrP synthesis due to a side effect of the proteasomal inhibitor on the CMV promoter used by $\mathrm{Ma}$ et $\mathrm{al}^{162}$ Drisaldi et al ${ }^{161}$ hypothesize that the mechanism of PrP accumulation may be due to stabilization of transcription or translation factors or to activation of signaling pathways that impinge on transcription of the promoter. In addition, Roucou et $\mathrm{al}^{155}$ found that PrP accumulation and passage through the ERAD pathway was not toxic in human primary neurons or human neuroblastoma cell lines. ${ }^{155,243}$

Another transgenic mouse was created that expressed additional octapeptide repeats, similar to a human inherited prion mutation. ${ }^{120}$ These mice express nine additional octapeptide repeats (PG14) and develop neurological disease characterized clinically by ataxia. Histologically, there is massive cerebellar granule cell loss, PrP accumulation and astrogliosis. This disease is not transmissible to wild-type mice, and the lesion is not reported in any of the prion strains that have been typed in mice, indicating that this disease is not part of the TSE spectrum and is a disease of protein overexpression.

Table I: Mouse models and functional studies

\begin{tabular}{|c|c|c|c|}
\hline Mouse & $\begin{array}{c}\text { Molecular } \\
\text { Effect }\end{array}$ & Lesion & Reference \\
\hline $\operatorname{PrP}^{000}$ & $\begin{array}{l}\text { Knock out } 4-187 \text { of } \\
\text { ORF }\end{array}$ & $\begin{array}{l}\text { Altered circadian rhythm, } \\
+/ \text { - seizures }\end{array}$ & $(225)$ \\
\hline $\operatorname{PrP}^{\mathrm{O} \times \mathrm{P}}$ & $\begin{array}{l}\text { Addition of SHPrP } \\
\text { cDNA }\end{array}$ & $\begin{array}{l}\text { Myopathy, neuropathy, } \\
\text { spongiform degeneration } \\
\text { CNS }\end{array}$ & (234) \\
\hline Shmerling mouse & $\begin{array}{l}\text { N-terminal } \\
\text { truncation }\end{array}$ & $\begin{array}{l}\text { Cerebellar granule cell } \\
\text { loss }\end{array}$ & (247) \\
\hline Hegde Ctm mouse & $\begin{array}{l}\text { Valine to alanine } \\
\text { substitutions } 113 \text {, } \\
115,118\end{array}$ & $\begin{array}{l}\text { Vacuolation, } \\
\text { hippocampus, piriform } \\
\text { cortex }\end{array}$ & (248) \\
\hline PG14 mouse & $\begin{array}{l}9 \text { additional } \\
\text { octapeptide repeats }\end{array}$ & $\begin{array}{l}\text { Cerebellar granule cell } \\
\text { loss }\end{array}$ & (120) \\
\hline $\begin{array}{l}\text { Ma cytosolic PrP } \\
\text { mouse }\end{array}$ & $\begin{array}{l}\mathrm{N} \text { and } \mathrm{C} \text { terminal } \\
\text { truncations }\end{array}$ & $\begin{array}{l}\text { Cerebellar granule cell } \\
\text { loss }\end{array}$ & (162) \\
\hline Sakaguchi $\mathrm{PrP}^{-*}$ & $\begin{array}{l}\text { Entire coding exon } \\
\text { knockout strategy }\end{array}$ & $\begin{array}{l}\text { Cerebellar Purkinje cell } \\
\text { loss }\end{array}$ & (230) \\
\hline $\operatorname{PrP} P^{P 102 L}$ & $\begin{array}{l}8 \text { fold } \\
\text { overexpression of } \\
\text { P102L }\end{array}$ & $\begin{array}{l}\text { Cerebral and brainstem } \\
\text { spongiform degeneration }\end{array}$ & (249) \\
\hline
\end{tabular}


Overall, these data suggest that the transgenic overexpression of a mutant prion protein in mice can result in a disease with neurological signs and pathological changes in the nervous system. However, none of these mutant forms of PrP have been shown to be transmissible to wild-type mice. These diseases cannot therefore be considered "transmissible" spongiform encephalopathies and are therefore diseases of overexpression of a protein in neurons that result in neuronal dysfunction and degeneration. The overexpression of other proteins may also result in neurological disease e.g. Syrian Hamster $\operatorname{PrP},{ }^{237} \alpha_{\mathrm{B}^{-}}$ adrenergic receptor, ${ }^{244}$ neurofilament proteins (NF-L, peripherin $)^{245}$ and G-protein coupled, protease-activated receptor for thrombin. ${ }^{246}$ Therefore, we should not be surprised that the expression of a protein above physiological levels may disrupt metabolic pathways and result in degeneration.

\section{Conclusions}

While the prion protein is the subject of numerous investigations, which have provided important scientific insight into disease and function, a number of important questions remain to be answered. Is prion protein the transmissible agent of prion diseases or is it the susceptibility factor that allows the manifestation of the disease? Are the prion protein functions important or are they part of a backup system that reiterates these functions? Are the genetic mutations truly reproducing the clinical and pathological manifestations of the disease in animal models? Clearly, much more work is required to solve these answers. Thus, future investigations promise continuing exciting results for this very unconventional protein.

\section{ACKNOWLEDGEMENTS}

This work was supported by the National Institutes of Health 1RO1 NS40431, Canadian Institutes for Health Research MOP49594 and Fonds de recherche en Santé du Québec to ALB.

\section{REFERENCES}

1. Wechselberger C, Wurm S, Pfarr W, Hoglinger O. The physiological functions of prion protein. Exp Cell Res. 2002;281(1):1-8.

2. Collinge J. Prion diseases of humans and animals: their causes and molecular basis. Annu Rev Neurosci. 2001;24:519-50.

3. Williams ES, Young S. Chronic wasting disease of captive mule deer: a spongiform encephalopathy. J Wildl Dis. 1980;16(1):8998.

4. Wells GA, Scott AC, Johnson CT, Gunning RF, Hancock RD, Jeffrey M, et al. A novel progressive spongiform encephalopathy in cattle. Vet Rec. 1987;121(18):419-20.

5. Wyatt JM, Pearson GR, Smerdon TN, Gruffydd-Jones TJ, Wells GA, Wilesmith JW. Naturally occurring scrapie-like spongiform encephalopathy in five domestic cats. Vet Rec. 1991;129(11):233-6.

6. Belay ED. Transmissible spongiform encephalopathies in humans. Annu Rev Microbiol. 1999;53:283-314.

7. Collinge J. Variant Creutzfeldt-Jakob disease. Lancet. 1999;354(9175):317-23.

8. Stack MJ, Balachandran A, Chaplin M, Davis L, Czub S, Miller B. The first Canadian indigenous case of bovine spongiform encephalopathy (BSE) has molecular characteristics for prion protein that are similar to those of BSE in the United Kingdom but differ from those of chronic wasting disease in captive elk and deer. Can Vet J. 2004;45(10):825-30.
9. Gajdusek DC, Zigas V. Degenerative disease of the central nervous system in New Guinea; the endemic occurrence of kuru in the native population. N Engl J Med. 1957;257(20):974-8.

10. Gajdusek DC, Gibbs CJ, Alpers M. Experimental transmission of a Kuru-like syndrome to chimpanzees. Nature. 1966;209(25): 794-6.

11. Bernoulli C, Siegfried J, Baumgartner G, Regli F, Rabinowicz T, Gajdusek DC, et al. Danger of accidental person-to-person transmission of Creutzfeldt-Jakob disease by surgery. Lancet. 1977;1(8009):478-9.

12. Duffy P, Wolf J, Collins G, DeVoe AG, Streeten B, Cowen D. Letter: Possible person-to-person transmission of CreutzfeldtJakob disease. N Engl J Med. 1974;290(12):692-3.

13. Thadani V, Penar PL, Partington J, Kalb R, Janssen R, Schonberger $\mathrm{LB}$, et al. Creutzfeldt-Jakob disease probably acquired from a cadaveric dura mater graft. Case report. J Neurosurg. 1988; 69(5):766-9.

14. Cochius JI, Burns RJ, Blumbergs PC, Mack K, Alderman CP. Creutzfeldt-Jakob disease in a recipient of human pituitaryderived gonadotrophin. Aust N Z J Med. 1990;20(4):592-3.

15. Brown P, Cathala F, Raubertas RF, Gajdusek DC, Castaigne P. The epidemiology of Creutzfeldt-Jakob disease: conclusion of a 15year investigation in France and review of the world literature. Neurology. 1987;37(6):895-904.

16. Collinge J. Human prion diseases and bovine spongiform encephalopathy (BSE). Hum Mol Genet. 1997;6(10):1699-705.

17. Prusiner SB. Prions. Proc Natl Acad Sci USA. 1998;95(23): 13363-83.

18. Goldfarb LG, Brown P, Haltia M, Cathala F, McCombie WR, Kovanen J, et al. Creutzfeldt-Jakob disease cosegregates with the codon 178Asn PRNP mutation in families of European origin. Ann Neurol. 1992;31(3):274-81.

19. Goldfarb LG, Petersen RB, Tabaton M, Brown P, LeBlanc AC, Montagna $\mathrm{P}$, et al. Fatal familial insomnia and familial Creutzfeldt-Jakob disease: disease phenotype determined by a DNA polymorphism. Science. 1992;258(5083):806-8.

20. Finckh U, Muller-Thomsen T, Mann U, Eggers C, Marksteiner J, Meins $\mathrm{W}$, et al. High prevalence of pathogenic mutations in patients with early-onset dementia detected by sequence analyses of four different genes. Am J Hum Genet. 2000;66(1):110-7.

21. Owen F, Poulter M, Lofthouse R, Collinge J, Crow TJ, Risby D, et al. Insertion in prion protein gene in familial Creutzfeldt-Jakob disease. Lancet. 1989;1(8628):51-2.

22. Budka H, Aguzzi A, Brown P, Brucher JM, Bugiani O, Gullota F, et al. Neuropathological diagnosis criteria for Creutzfeldt-Jakob disease (CJD) and other human spongiform encephalopathies (prion diseases). Brain Pathology. 1995;5:459-66.

23. Dlouhy SR, Hsiao K, Farlow MR, Foroud T, Conneally PM, Johnson P, et al. Linkage of the Indiana kindred of GerstmannStraussler-Scheinker disease to the prion protein gene. Nat Genet. 1992;1(1):64-7.

24. Medori R, Tritschler H, LeBlanc A, Villare F, Manetto V, Chen H, et al. Fatal familial insomnia is a prion disease with a mutation at codon 178 of the prion protein gene. New Engl J Med. 1992;326:444-9.

25. Nitrini R, Rosemberg S, Passos-Bueno MR, Lughetti $P$, Papadopoulos M, Carrilho PE, et al. Familial Spongiform Encephalopathy with distinct clinico-pathological features associated with a novel prion protein gene mutation at codon 183. Ann. Neurol. 1997;42:138-46.

26. Parchi P, Castellani R, Capellari S, Ghetti B, Young K, Chen SG, et al. Molecular basis of phenotypic variability in sporadic Creutzfeldt-Jakob disease. Ann Neurol. 1996;39(6):767-78.

27. Prusiner SB. The prion diseases. Brain Pathol. 1998;8(3):499-513.

28. Mastrianni JA, Nixon R, Layzer R, Telling GC, Han D, DeArmond SJ, et al. Prion protein conformation in a patient with sporadic fatal insomnia. N Engl J Med. 1999;340(21):1630-8.

29. Lampert PW, Gajdusek DC, Gibbs CJ, Jr. Subacute spongiform virus encephalopathies. Scrapie, Kuru and Creutzfeldt-Jakob disease: a review. Am J Pathol. 1972;68(3):626-52. 
30. Bell JE, Ironside JW. Neuropathology of spongiform encephalopathies in humans. Br Med Bull. 1993;49(4):738-77.

31. Bruce ME, Fraser H. Scrapie strain variation and its implications. Curr Top Microbiol Immunol. 1991;172:125-38.

32. Jeffrey M, Fraser JR, Halliday WG, Fowler N, Goodsir CM, Brown DA. Early unsuspected neuron and axon terminal loss in scrapieinfected mice revealed by morphometry and immunocytochemistry. Neuropathol Appl Neurobiol. 1995;21(1):41-9.

33. Wells GA, Hancock RD, Cooley WA, Richards MS, Higgins RJ, David GP. Bovine spongiform encephalopathy: diagnostic significance of vacuolar changes in selected nuclei of the medulla oblongata. Vet Rec. 1989;125(21):521-4.

34. Wells GA, Wilesmith JW, McGill IS. Bovine spongiform encephalopathy: a neuropathological perspective. Brain Pathol. 1991;1(2):69-78.

35. Ryder SJ, Hawkins SA, Dawson M, Wells GA. The neuropathology of experimental bovine spongiform encephalopathy in the pig. $\mathbf{J}$ Comp Pathol. 2000;122(2-3):131-43.

36. Wells GA. Pathology of nonhuman spongiform encephalopathies: variations and their implications for pathogenesis. Dev Biol Stand. 1993;80:61-9.

37. Manuelidis EE, Gorgacz EJ, Manuelidis L. Interspecies transmission of Creutzfeldt-Jakob disease to Syrian hamsters with reference to clinical syndromes and strains of agent. Proc Natl Acad Sci U S A. 1978;75(7):3432-6.

38. Jeffrey M, Scott JR, Fraser H. Scrapie inoculation of mice: light and electron microscopy of the superior colliculi. Acta Neuropathol (Berl). 1991;81(5):562-71.

39. Fraser H, Dickinson AG. The sequential development of the brain lesion of scrapie in three strains of mice. J Comp Pathol. 1968;78(3):301-11.

40. Lasmezas CI, Deslys JP, Robain O, Jaegly A, Beringue V, Peyrin $\mathrm{JM}$, et al. Transmission of the BSE agent to mice in the absence of detectable abnormal prion protein. Science. 1997;275(5298):402-5.

41. Sato Y, Ohta M, Tateishi J. Experimental transmission of human subacute spongiform encephalopathy to small rodents. II. Ultrastructural study of spongy state in the gray and white matter. Acta Neuropathol (Berl). 1980;51(2):135-40.

42. Kim JH, Manuelidis EE. Ultrastructural findings in experimental Creutzfeldt-Jakob disease in guinea pigs. J Neuropathol Exp Neurol. 1983;42(1):29-43.

43. Kim JH, Manuelidis EE. Serial ultrastructural study of experimental Creutzfeldt-Jacob disease in guinea pigs. Acta Neuropathol (Berl). 1986;69(1-2):81-90.

44. Baker HF, Duchen LW, Jacobs JM, Ridley RM. Spongiform encephalopathy transmitted experimentally from CreutzfeldtJakob and familial Gerstmann-Straussler-Scheinker diseases. Brain. 1990;113 ( Pt 6):1891-909.

45. Liberski PP, Yanagihara R, Nerurkar V, Gajdusek DC. Further ultrastructural studies of lesions produced in the optic nerve by tumor necrosis factor alpha (TNF-alpha): a comparison with experimental Creutzfeldt-Jakob disease. Acta Neurobiol Exp (Wars). 1994;54(3):209-18.

46. Bruce ME. Agent replication dynamics in a long incubation period model of mouse scrapie. J Gen Virol. 1985;66 (Pt 12):2517-22.

47. Prusiner SB. Novel proteinaceous infectious particles cause scrapie. Science. 1982;216(4542):136-44.

48. Baringer JR, Bowman KA, Prusiner SB. Replication of the scrapie agent in hamster brain precedes neuronal vacuolation. J Neuropathol Exp Neurol. 1983;42(5):539-47.

49. Marsh RF, Sipe JC, Morse SS, Hanson RP. Transmissible mink encephalopathy. Reduced spongiform degeneration in aged mink of the Chediak-Higashi genotype. Lab Invest. 1976;34(4):381-6.

50. Yagi H, Irino M, Matsushita T, Katoh S, Umezawa M, Tsuboyama $\mathrm{T}$, et al. Spontaneous spongy degeneration of the brain stem in SAM-P/8 mice, a newly developed memory-deficient strain. J Neuropathol Exp Neurol. 1989;48(5):577-90.
51. Bundza A, Charlton KM. Comparison of spongiform lesions in experimental scrapie and rabies in skunks. Acta Neuropathol (Berl). 1988;76(3):275-80.

52. Sharpe AH, Hunter JJ, Chassler P, Jaenisch R. Role of abortive retroviral infection of neurons in spongiform CNS degeneration. Nature. 1990;346(6280):181-3.

53. Jeffrey M, Goodbrand IA, Goodsir CM. Pathology of the transmissible spongiform encephalopathies with special emphasis on ultrastructure. Micron. 1995;26(3):277-98.

54. Jeffrey M, Goodsir CM, Bruce ME, McBride PA, Scott JR, Halliday WG. Infection specific prion protein $(\operatorname{PrP})$ accumulates on neuronal plasmalemma in scrapie infected mice. Neurosci Lett. 1992;147(1):106-9.

55. Jeffrey M, Goodsir CM, Bruce ME, McBride PA, Fowler N, Scott JR. Murine scrapie-infected neurons in vivo release excess prion protein into the extracellular space. Neurosci Lett. 1994;174(1):39-42.

56. Mackenzie A. Immunohistochemical demonstration of glial fibrillary acidic protein in scrapie. J Comp Pathol. 1983;93(2):251-9.

57. Hudson AJ, Farrell MA, Kalnins R, Kaufmann JC. GerstmannStraussler-Scheinker disease with coincidental familial onset. Ann Neurol. 1983;14(6):670-8.

58. Norenberg MD. Astrocyte responses to CNS injury. J Neuropathol Exp Neurol. 1994;53(3):213-20.

59. Berg LJ. Insights into the role of the immune system in prion diseases. Proc Natl Acad Sci U S A. 1994;91(2):429-32.

60. Williams AE, van Dam AM, Man AHWK, Berkenbosch F, Eikelenboom P, Fraser H. Cytokines, prostaglandins and lipocortin-1 are present in the brains of scrapie-infected mice. Brain Res. 1994;654(2):200-6.

61. Kim JI, Ju WK, Choi JH, Choi E, Carp RI, Wisniewski HM, et al. Expression of cytokine genes and increased nuclear factor-kappa B activity in the brains of scrapie-infected mice. Brain Res Mol Brain Res. 1999;73(1-2):17-27.

62. Klatzo I, Gajdusek DC, Zigas V. Pathology of Kuru. Lab Invest. 1959;8(4):799-847.

63. DeArmond SJ, McKinley MP, Barry RA, Braunfeld MB, McColloch JR, Prusiner SB. Identification of prion amyloid filaments in scrapie-infected brain. Cell. 1985;41(1):221-35.

64. Wisniewski HM, Vorbrodt AW, Wegiel J, Morys J, Lossinsky AS. Ultrastructure of the cells forming amyloid fibers in Alzheimer disease and scrapie. Am J Med Genet Suppl. 1990;7:287-97.

65. Alper T, Haig DA, Clarke MC. The exceptionally small size of the scrapie agent. Biochem Biophys Res Commun. 1966;22(3): 278-84.

66. Pattison IH, Jones KM. The possible nature of the transmissible agent of scrapie. Vet Rec. 1967;80(1):2-9.

67. Bolton DC, McKinley MP, Prusiner SB. Identification of a protein that purifies with the scrapie prion. Science. 1982;218(4579): 1309-11.

68. Oesch B, Westaway D, Walchli M, McKinley MP, Kent SB, Aebersold R, et al. A cellular gene encodes scrapie PrP 27-30 protein. Cell. 1985;40(4):735-46.

69. Caughey B, Raymond GJ. The scrapie-associated form of PrP is made from a cell surface precursor that is both protease- and phospholipase-sensitive. J Biol Chem. 1991;266(27):18217-23.

70. Borchelt DR, Scott M, Taraboulos A, Stahl N, Prusiner SB. Scrapie and cellular prion proteins differ in their kinetics of synthesis and topology in cultured cells. J Cell Biol. 1990;110(3):743-52.

71. Pan KM, Baldwin M, Nguyen J, Gasset M, Serban A, Groth D, et al. Conversion of alpha-helices into beta-sheets features in the formation of the scrapie prion proteins. Proc Natl Acad Sci USA. 1993;90(23):10962-6.

72. Telling GC, Haga T, Torchia M, Tremblay P, DeArmond SJ, Prusiner SB. Interactions between wild-type and mutant prion proteins modulate neurodegeneration in transgenic mice. Genes Dev. 1996;10(14):1736-50.

73. Westaway D, Telling G, Priola S. Prions. Proc Natl Acad Sci U S A. 1998;95(19):11030-1. 
74. Telling GC, Scott M, Mastrianni J, Gabizon R, Torchia M, Cohen $\mathrm{FE}$, et al. Prion propagation in mice expressing human and chimeric PrP transgenes implicates the interaction of cellular PrP with another protein. Cell. 1995;83(1):79-90.

75. Rohwer RG. Scrapie infectious agent is virus-like in size and susceptibility to inactivation. Nature. 1984;308(5960):658-62.

76. Narang H. A critical review of the nature of the spongiform encephalopathy agent: protein theory versus virus theory. Exp Biol Med (Maywood). 2002;227(1):4-19.

77. Narang HK. Evidence that single-stranded DNA wrapped around the tubulofilamentous particles termed "nemaviruses" is the genome of the scrapie agent. Res Virol. 1998;149(6):375-82.

78. Kimberlin RH, Walker CA, Fraser H. The genomic identity of different strains of mouse scrapie is expressed in hamsters and preserved on reisolation in mice. J Gen Virol. 1989;70(Pt 8):2017-25

79. Somerville RA. TSE agent strains and PrP: reconciling structure and function. Trends Biochem Sci. 2002;27(12):606-12.

80. Rico A. Prion: toxic or infectious agent? Med Hypotheses. 2003;60(2):209-14.

81. Kimberlin RH. Scrapie agent: prions or virinos? Nature. 1982;297(5862):107-8.

82. Manuelidis EE, Manuelidis L. A transmissible Creutzfeldt-Jakob disease-like agent is prevalent in the human population. Proc Natl Acad Sci U S A. 1993;90(16):7724-8.

83. Manuelidis L, Sklaviadis T, Akowitz A, Fritch W. Viral particles are required for infection in neurodegenerative Creutzfeldt-Jakob disease. Proc Natl Acad Sci USA. 1995;92(11):5124-8.

84. Bastian FO. Spiroplasma as a candidate agent for the transmissible spongiform encephalopathies. J Neuropathol Exp Neurol. 2005;64(10):833-8.

85. Taraboulos A, Serban D, Prusiner SB. Scrapie prion proteins accumulate in the cytoplasm of persistently infected cultured cells. J Cell Biol. 1990;110(6):2117-32.

86. Swietnicki W, Petersen RB, Gambetti P, Surewicz WK. Familial mutations and the thermodynamic stability of the recombinant human prion protein. J Biol Chem. 1998;273(47):31048-52.

87. Mastrangelo P, Westaway D. Biology of the prion gene complex. Biochem Cell Biol. 2001;79(5):613-28.

88. Ma J, Lindquist S. De novo generation of a PrPSc-like conformation in living cells. Nat Cell Biol. 1999;1(6):358-61.

89. Qin K, Yang DS, Yang Y, Chishti MA, Meng LJ, Kretzschmar HA, et al. Copper(II)-induced conformational changes and protease resistance in recombinant and cellular PrP. Effect of protein age and deamidation. J Biol Chem. 2000;275(25):19121-31

90. Brown DR, Hafiz F, Glasssmith LL, Wong BS, Jones IM, Clive C, et al. Consequences of manganese replacement of copper for prion protein function and proteinase resistance. EMBO J. 2000;19(6):1180-6.

91. Klein MA, Frigg R, Flechsig E, Raeber AJ, Kalinke U, Bluethmann $\mathrm{H}$, et al. A crucial role for $\mathrm{B}$ cells in neuroinvasive scrapie. Nature. 1997;390(6661):687-90.

92. Glatzel M, Heppner FL, Albers KM, Aguzzi A. Sympathetic innervation of lymphoreticular organs is rate limiting for prion neuroinvasion. Neuron. 2001;31(1):25-34.

93. Nicotera P. A route for prion neuroinvasion. Neuron. 2001;31(3):345-8

94. Montrasio F, Frigg R, Glatzel M, Klein MA, Mackay F, Aguzzi A, et al. Impaired prion replication in spleens of mice lacking functional follicular dendritic cells. Science. 2000;288(5469):1257-9.

95. Beekes M, McBride PA, Baldauf E. Cerebral targeting indicates vagal spread of infection in hamsters fed with scrapie. J Gen Virol. 1998;79(Pt 3):601-7.

96. Prusiner SB. Molecular biology of prion diseases. Science. 1991;252(5012):1515-22.

97. Jarrett JT, Lansbury PT, Jr. Seeding "one-dimensional crystallization" of amyloid: a pathogenic mechanism in Alzheimer's disease and scrapie? Cell. 1993;73(6):1055-8.

98. Riesner D, Kellings K, Post K, Wille H, Serban H, Groth D, et al. Disruption of prion rods generates $10-\mathrm{nm}$ spherical particles having high alpha-helical content and lacking scrapie infectivity. J Virol. 1996;70(3):1714-22.
99. Castilla J, Saa P, Hetz C, Soto C. In vitro generation of infectious scrapie prions. Cell. 2005;121(2):195-206.

100. Bueler H, Aguzzi A, Sailer A, Greiner RA, Autenried P, Aguet M, et al. Mice devoid of PrP are resistant to scrapie. Cell. 1993;73(7):1339-47.

101. Brandner S, Isenmann S, Raeber A, Fischer M, Sailer A, Kobayashi $\mathrm{Y}$, et al. Normal host prion protein necessary for scrapie-induced neurotoxicity. Nature. 1996;379(6563):339-43.

102. Brandner S, Isenmann S, Kuhne G, Aguzzi A. Identification of the end stage of scrapie using infected neural grafts. Brain Pathol. $1998 ; 8(1): 19-27$.

103. Blattler T, Brandner S, Raeber AJ, Klein MA, Voigtlander T, Weissmann C, et al. PrP-expressing tissue required for transfer of scrapie infectivity from spleen to brain. Nature. 1997;389(6646):69-73.

104. Fraser H, Brown KL, Stewart K, McConnell I, McBride P, Williams A. Replication of scrapie in spleens of SCID mice follows reconstitution with wild-type mouse bone marrow. J Gen Virol. 1996;77(Pt 8):1935-40.

105. Klein MA, Frigg R, Raeber AJ, Flechsig E, Hegyi I, Zinkernagel $\mathrm{RM}$, et al. PrP expression in B lymphocytes is not required for prion neuroinvasion. Nat Med. 1998;4(12):1429-33.

106. Jeffrey M, Halliday WG, Bell J, Johnston AR, MacLeod NK, Ingham $\mathrm{C}$, et al. Synapse loss associated with abnormal PrP precedes neuronal degeneration in the scrapie-infected murine hippocampus. Neuropathol Appl Neurobiol. 2000;26(1):41-54.

107. Belichenko PV, Brown D, Jeffrey M, Fraser JR. Dendritic and synaptic alterations of hippocampal pyramidal neurones in scrapie-infected mice. Neuropathol Appl Neurobiol. 2000;26(2):143-9.

108. Siso S, Puig B, Varea R, Vidal E, Acin C, Prinz M, et al. Abnormal synaptic protein expression and cell death in murine scrapie. Acta Neuropathol (Berl). 2002;103(6):615-26.

109. Kretzschmar HA, Stowring LE, Westaway D, Stubblebine WH, Prusiner SB, Dearmond SJ. Molecular cloning of a human prion protein cDNA. DNA. 1986;5(4):315-24.

110. Puckett C, Concannon P, Casey C, Hood L. Genomic structure of the human prion protein gene. Am J Hum Genet. 1991;49(2):320-9.

111. Lee IY, Westaway D, Smit AF, Wang K, Seto J, Chen L, et al. Complete genomic sequence and analysis of the prion protein gene region from three mammalian species. Genome Res. 1998;8(10):1022-37.

112. Mahal SP, Asante EA, Antoniou M, Collinge J. Isolation and functional characterisation of the promoter region of the human prion protein gene. Gene. 2001;268(1-2):105-14.

113. Liemann S, Glockshuber R. Influence of amino acid substitutions related to inherited human prion diseases on the thermodynamic stability of the cellular prion protein. Biochemistry. 1999:38(11):3258-67

114. Yin S, Yu S, Li C, Wong P, Chang B, Xiao F, et al. Prion proteins with insertion mutations have altered $\mathrm{N}$-terminal conformation and increased ligand binding activity and are more susceptible to oxidative attack. J Biol Chem. 2006;281(16):10698-705.

115. Apetri AC, Surewicz K, Surewicz WK. The effect of diseaseassociated mutations on the folding pathway of human prion protein. J Biol Chem. 2004;279(17):18008-14.

116. Zimmermann K, Turecek PL, Schwarz HP. Genotyping of the prion protein gene at codon 129. Acta Neuropathol (Berl). 1999;97(4):355-8

117. Palmer MS, Dryden AJ, Hughes JT, Collinge J. Homozygous prion protein genotype predisposes to sporadic Creutzfeldt-Jakob disease. Nature. 1991;352(6333):340-2.

118. Collinge J, Sidle KC, Meads J, Ironside J, Hill AF. Molecular analysis of prion strain variation and the aetiology of 'new variant' CJD. Nature. 1996;383(6602):685-90.

119. Peden AH, Head MW, Ritchie DL, Bell JE, Ironside JW. Preclinical vCJD after blood transfusion in a PRNP codon 129 heterozygous patient. Lancet. 2004;364(9433):527-9.

120. Chiesa R, Piccardo P, Ghetti B, Harris DA. Neurological illness in transgenic mice expressing a prion protein with an insertional mutation. Neuron. 1998;21(6):1339-51. 
121. Bendheim PE, Brown HR, Rudelli RD, Scala LJ, Goller NL, Wen GY, et al. Nearly ubiquitous tissue distribution of the scrapie agent precursor protein. Neurology. 1992;42(1):149-56.

122. Brown DR, Schmidt B, Groschup MH, Kretzschmar HA. Prion protein expression in muscle cells and toxicity of a prion protein fragment. Eur J Cell Biol. 1998;75(1):29-37.

123. Wopfner F, Weidenhofer G, Schneider R, von Brunn A, Gilch S, Schwarz TF, et al. Analysis of 27 mammalian and 9 avian PrPs reveals high conservation of flexible regions of the prion protein. J Mol Biol. 1999;289(5):1163-78.

124. Simonic T, Duga S, Strumbo B, Asselta R, Ceciliani F, Ronchi S. cDNA cloning of turtle prion protein. FEBS Lett. 2000;469(1):33-8.

125. Shaked Y, Rosenmann H, Talmor G, Gabizon R. A C-terminaltruncated PrP isoform is present in mature sperm. J Biol Chem. 1999;274(45):32153-8.

126. Williams WM, Stadtman ER, Moskovitz J. Ageing and exposure to oxidative stress in vivo differentially affect cellular levels of $\operatorname{PrP}$ in mouse cerebral microvessels and brain parenchyma. Neuropathol Appl Neurobiol. 2004;30(2):161-8.

127.van Rheede T, Smolenaars MM, Madsen O, de Jong WW. Molecular evolution of the mammalian prion protein. Mol Biol Evol. 2003;20(1):111-21.

128. Hegde RS, Mastrianni JA, Scott MR, DeFea KA, Tremblay P, Torchia M, et al. A transmembrane form of the prion protein in neurodegenerative disease. Science. 1998;279(5352):827-34.

129. Nunziante M, Gilch S, Schatzl HM. Essential role of the prion protein $\mathrm{N}$ terminus in subcellular trafficking and half-life of cellular prion protein. J Biol Chem. 2003;278(6):3726-34

130. Stahl N, Prusiner SB. Prions and prion proteins. FASEB J. 1991;5(13):2799-807.

131. Rudd PM, Endo T, Colominas C, Groth D, Wheeler SF, Harvey DJ, et al. Glycosylation differences between the normal and pathogenic prion protein isoforms. Proc Natl Acad Sci U S A. 1999;96(23):13044-9.

132. Caughey B, Race RE, Ernst D, Buchmeier MJ, Chesebro B. Prion protein biosynthesis in scrapie-infected and uninfected neuroblastoma cells. J Virol. 1989;63(1):175-81.

133. Harris DA. Trafficking, turnover and membrane topology of PrP. Br Med Bull. 2003;66:71-85

134. Stahl N, Baldwin MA, Hecker R, Pan KM, Burlingame AL, Prusiner SB. Glycosylinositol phospholipid anchors of the scrapie and cellular prion proteins contain sialic acid. Biochemistry. 1992;31(21):5043-53

135. Rudd PM, Merry AH, Wormald MR, Dwek RA. Glycosylation and prion protein. Curr Opin Struct Biol. 2002;12(5):578-86.

136. Wiseman F, Cancellotti E, Manson J. Glycosylation and misfolding of PrP. Biochem Soc Trans. 2005;33(Pt 5):1094-5.

137. Ermonval M, Mouillet-Richard S, Codogno P, Kellermann O, Botti J. Evolving views in prion glycosylation: functional and pathological implications. Biochimie. 2003;85(1-2):33-45.

138. Pan T, Li R, Wong BS, Liu T, Gambetti P, Sy MS. Heterogeneity of normal prion protein in two- dimensional immunoblot: presence of various glycosylated and truncated forms. J Neurochem. 2002;81(5):1092-101.

139. Naslavsky N, Stein R, Yanai A, Friedlander G, Taraboulos A. Characterization of detergent-insoluble complexes containing the cellular prion protein and its scrapie isoform. J Biol Chem. 1997;272(10):6324-31.

140. Gilch S, Kehler C, Schatzl HM. The prion protein requires cholesterol for cell surface localization. Mol Cell Neurosci. 2006;31(2):346-53.

141. Critchley P, Kazlauskaite J, Eason R, Pinheiro TJ. Binding of prion proteins to lipid membranes. Biochem Biophys Res Commun. 2004;313(3):559-67.

142. Borchelt DR, Taraboulos A, Prusiner SB. Evidence for synthesis of scrapie prion proteins in the endocytic pathway. J Biol Chem. 1992;267(23):16188-99.

143. Shyng SL, Huber MT, Harris DA. A prion protein cycles between the cell surface and an endocytic compartment in cultured neuroblastoma cells. J Biol Chem. 1993;268(21):15922-8.
144. Pauly PC, Harris DA. Copper stimulates endocytosis of the prion protein. J Biol Chem. 1998;273(50):33107-10.

145.Lee KS, Magalhaes AC, Zanata SM, Brentani RR, Martins VR, Prado MA. Internalization of mammalian fluorescent cellular prion protein and $\mathrm{N}$-terminal deletion mutants in living cells. J Neurochem. 2001;79(1):79-87.

146. Sunyach C, Jen A, Deng J, Fitzgerald KT, Frobert Y, Grassi J, et al. The mechanism of internalization of glycosylphosphatidylinositol-anchored prion protein. Embo J. 2003;22(14): 3591-601.

147. Shyng SL, Lehmann S, Moulder KL, Harris DA. Sulfated glycans stimulate endocytosis of the cellular isoform of the prion protein, PrPC, in cultured cells. J Biol Chem. 1995;270(50):30221-9.

148. Vey M, Pilkuhn S, Wille H, Nixon R, DeArmond SJ, Smart EJ, et al. Subcellular colocalization of the cellular and scrapie prion proteins in caveolae-like membranous domains. Proc Natl Acad Sci USA. 1996;93(25):14945-9.

149. Gaidarov I, Keen JH. Phosphoinositide-AP-2 interactions required for targeting to plasma membrane clathrin-coated pits. J Cell Biol. 1999;146(4):755-64.

150. Nichols BJ, Kenworthy AK, Polishchuk RS, Lodge R, Roberts TH, Hirschberg K, et al. Rapid cycling of lipid raft markers between the cell surface and Golgi complex. J Cell Biol. 2001; 153(3):529-41

151. Shyng SL, Heuser JE, Harris DA. A glycolipid-anchored prion protein is endocytosed via clathrin-coated pits. J Cell Biol. 1994; 125(6): $1239-50$.

152.Pelkmans L, Kartenbeck J, Helenius A. Caveolar endocytosis of simian virus 40 reveals a new two-step vesicular-transport pathway to the ER. Nat Cell Biol. 2001;3(5):473-83.

153. Laine J, Marc ME, Sy MS, Axelrad H. Cellular and subcellular morphological localization of normal prion protein in rodent cerebellum. Eur J Neurosci. 2001;14(1):47-56.

154. Mironov A, Jr., Latawiec D, Wille H, Bouzamondo-Bernstein E, Legname G, Williamson RA, et al. Cytosolic prion protein in neurons. J Neurosci. 2003;23(18):7183-93.

155. Roucou X, Guo Q, Zhang Y, Goodyer CG, LeBlanc AC. Cytosolic prion protein is not toxic and protects against Bax-mediated cell death in human primary neurons. J Biol Chem. 2003; 278(42):40877-81.

156. Ma J, Lindquist S. Conversion of PrP to a self-perpetuating PrPSclike conformation in the cytosol. Science. 2002;298(5599): 1785-8.

157. Yedidia Y, Horonchik L, Tzaban S, Yanai A, Taraboulos A. Proteasomes and ubiquitin are involved in the turnover of the wild-type prion protein. EMBO J. 2001;20(19):5383-91.

158. Zanusso G, Petersen RB, Taocong J, Jing Y, Kanoush R, Ferrari S, et al. Proteosomal degradation and $\mathrm{N}$-terminal protease resistance of the codon 145 mutant prion protein. J Biol Chem. 1999:274:23396-404.

159. Ma J, Lindquist S. Wild-type PrP and a mutant associated with prion disease are subject to retrograde transport and proteasome degradation. Proc Natl Acad Sci USA. 2001;98(26):14955-60.

160. Rane NS, Yonkovich JL, Hegde RS. Protection from cytosolic prion protein toxicity by modulation of protein translocation. EMBO J. 2004;23(23):4550-9.

161. Drisaldi B, Stewart RS, Adles C, Stewart LR, Quaglio E, Biasini E, et al. Mutant PrP is delayed in its exit from the endoplasmic reticulum, but neither wild-type nor mutant PrP undergoes retrotranslocation prior to proteasomal degradation. J Biol Chem. 2003;278(24):21732-43.

162. Ma J, Wollmann R, Lindquist S. Neurotoxicity and neurodegeneration when PrP accumulates in the cytosol. Science. 2002;298(5599):1781-5

163. Arnold JE, Tipler C, Laszlo L, Hope J, Landon M, Mayer RJ. The abnormal isoform of the prion protein accumulates in lateendosome-like organelles in scrapie-infected mouse brain. J Pathol. 1995;176(4):403-11.

164. Sales N, Rodolfo K, Hassig R, Faucheux B, Di Giamberardino L, Moya KL. Cellular prion protein localization in rodent and primate brain. Eur J Neurosci. 1998;10(7):2464-71.

165. Brown DR. Prion and prejudice: normal protein and the synapse. Trends Neurosci. 2001;24(2):85-90. 
166. Mallucci GR, Ratte S, Asante EA, Linehan J, Gowland I, Jefferys JG, et al. Post-natal knockout of prion protein alters hippocampal CA1 properties, but does not result in neurodegeneration. EMBO J. 2002;21(3):202-10.

167. Brown DR, Qin K, Herms JW, Madlung A, Manson J, Strome R, et al. The cellular prion protein binds copper in vivo. Nature. 1997;390(6661):684-7.

168. Jackson GS, Murray I, Hosszu LL, Gibbs N, Waltho JP, Clarke AR, et al. Location and properties of metal-binding sites on the human prion protein. Proc Natl Acad Sci USA. 2001;98(15): $8531-5$.

169. Haigh CL, Edwards K, Brown DR. Copper binding is the governing determinant of prion protein turnover. Mol Cell Neurosci. 2005; 30(2):186-96.

170. Brown DR, Besinger A. Prion protein expression and superoxide dismutase activity. Biochem J. 1998;334(Pt 2):423-9.

171. Rachidi W, Vilette D, Guiraud P, Arlotto M, Riondel J, Laude H, et al. Expression of prion protein increases cellular copper binding and antioxidant enzyme activities but not copper delivery. J Biol Chem. 2003;278(11):9064-72.

172. Jones S, Batchelor M, Bhelt D, Clarke AR, Collinge J, Jackson GS. Recombinant prion protein does not possess SOD-1 activity. Biochem J. 2005;392(Pt 2):309-12.

173. Brown DR, Schulz-Schaeffer WJ, Schmidt B, Kretzschmar HA. Prion protein-deficient cells show altered response to oxidative stress due to decreased SOD-1 activity. Exp Neurol. 1997; 146(1):104-12.

174. White AR, Collins SJ, Maher F, Jobling MF, Stewart LR, Thyer JM, et al. Prion protein-deficient neurons reveal lower glutathione reductase activity and increased susceptibility to hydrogen peroxide toxicity. Am J Pathol. 1999;155(5):1723-30.

175. Pereira GS, Walz R, Bonan CD, Battastini AM, Izquierdo I, Martins VR, et al. Changes in cortical and hippocampal ectonucleotidase activities in mice lacking cellular prion protein. Neurosci Lett. 2001;301(1):72-4

176. Watt NT, Hooper NM. The prion protein and neuronal zinc homeostasis. Trends Biochem Sci. 2003;28(8):406-10.

177.Edenhofer F, Rieger R, Famulok M, Wendler W, Weiss S, Winnacker EL. Prion protein PrPc interacts with molecular chaperones of the Hsp60 family. J Virol. 1996;70(7):4724-8.

178. Gabizon R, Meiner Z, Halimi M, Ben-Sasson SA. Heparin-like molecules bind differentially to prion-proteins and change their intracellular metabolic fate. J Cell Physiol. 1993;157(2):319-25.

179. Spielhaupter C, Schatzl HM. PrPC directly interacts with proteins involved in signaling pathways. J Biol Chem. 2001;276(48): 44604-12.

180. Graner E, Mercadante AF, Zanata SM, Forlenza OV, Cabral AL, Veiga SS, et al. Cellular prion protein binds laminin and mediates neuritogenesis. Brain Res Mol Brain Res. 2000;76(1): 85-92.

181. Rieger R, Edenhofer F, Lasmezas CI, Weiss S. The human 37-kDa laminin receptor precursor interacts with the prion protein in eukaryotic cells. Nat Med. 1997;3(12):1383-8.

182. Chen S, Mange A, Dong L, Lehmann S, Schachner M. Prion protein as trans-interacting partner for neurons is involved in neurite outgrowth and neuronal survival. Mol Cell Neurosci. 2003; 22(2):227-33

183. Steele AD, Emsley JG, Ozdinler PH, Lindquist S, Macklis JD. Prion protein $(\mathrm{PrPc})$ positively regulates neural precursor proliferation during developmental and adult mammalian neurogenesis. Proc Natl Acad Sci U S A. 2006;103(9):3416-21.

184. Mouillet-Richard S, Ermonval M, Chebassier C, Laplanche JL, Lehmann S, Launay JM, et al. Signal transduction through prion protein. Science. 2000;289(5486):1925-8

185. Chiarini LB, Freitas AR, Zanata SM, Brentani RR, Martins VR, Linden R. Cellular prion protein transduces neuroprotective signals. EMBO J. 2002;21(13):3317-26.

186.Zanata SM, Lopes MH, Mercadante AF, Hajj GN, Chiarini LB, Nomizo R, et al. Stress-inducible protein 1 is a cell surface ligand for cellular prion that triggers neuroprotection. EMBO J. 2002;21(13):3307-16
187. Tobler I, Gaus SE, Deboer T, Achermann P, Fischer M, Rulicke T, et al. Altered circadian activity rhythms and sleep in mice devoid of prion protein. Nature. 1996;380(6575):639-42.

188. Coitinho AS, Roesler R, Martins VR, Brentani RR, Izquierdo I. Cellular prion protein ablation impairs behavior as a function of age. Neuroreport. 2003;14(10):1375-9.

189. Walz R, Amaral OB, Rockenbach IC, Roesler R, Izquierdo I, Cavalheiro EA, et al. Increased sensitivity to seizures in mice lacking cellular prion protein. Epilepsia. 1999;40(12):1679-82.

190. Papassotiropoulos A, Wollmer MA, Aguzzi A, Hock C, Nitsch RM, de Quervain DJ. The prion gene is associated with human longterm memory. Hum Mol Genet. 2005;14(15):2241-6.

191. Colling SB, Collinge J, Jefferys JG. Hippocampal slices from prion protein null mice: disrupted $\mathrm{Ca}(2+)$-activated $\mathrm{K}+$ currents. Neurosci Lett. 1996;209(1):49-52.

192. Herms JW, Korte S, Gall S, Schneider I, Dunker S, Kretzschmar HA. Altered intracellular calcium homeostasis in cerebellar granule cells of prion protein-deficient mice. J Neurochem. 2000;75(4):1487-92.

193. Herms JW, Tings T, Dunker S, Kretzschmar HA. Prion protein affects $\mathrm{Ca} 2+-$ activated $\mathrm{K}+$ currents in cerebellar purkinje cells. Neurobiol Dis. 2001;8(2):324-30.

194. Collinge J, Whittington MA, Sidle KC, Smith CJ, Palmer MS, Clarke AR, et al. Prion protein is necessary for normal synaptic function. Nature. 1994;370(6487):295-7.

195.Lledo PM, Tremblay P, DeArmond SJ, Prusiner SB, Nicoll RA. Mice deficient for prion protein exhibit normal neuronal excitability and synaptic transmission in the hippocampus. Proc Natl Acad Sci U S A. 1996;93(6):2403-7.

196. Roesler R, Walz R, Quevedo J, de-Paris F, Zanata SM, Graner E, et al. Normal inhibitory avoidance learning and anxiety, but increased locomotor activity in mice devoid of $\operatorname{Pr} P(C)$. Brain Res Mol Brain Res. 1999;71(2):349-53.

197. Kristensson K, Feuerstein B, Taraboulos A, Hyun WC, Prusiner SB, DeArmond SJ. Scrapie prions alter receptor-mediated calcium responses in cultured cells. Neurology. 1993;43(11):2335-41.

198. Gabus C, Auxilien S, Pechoux C, Dormont D, Swietnicki W, Morillas M, et al. The prion protein has DNA strand transfer properties similar to retroviral nucleocapsid protein. J Mol Biol. 2001;307(4):1011-21.

199. Huang Y, Khorchid A, Gabor J, Wang J, Li X, Darlix JL, et al. The role of nucleocapsid and U5 stem/A-rich loop sequences in tRNA(3Lys) genomic placement and initiation of reverse transcription in human immunodeficiency virus type 1. J Virol. 1998;72(5):3907-15

200. Derrington EA, Darlix JL. The enigmatic multifunctionality of the prion protein. Drug News Perspect. 2002;15(4):206-19.

201. Adler V, Zeiler B, Kryukov V, Kascsak R, Rubenstein R, Grossman A. Small, highly structured RNAs participate in the conversion of human recombinant $\operatorname{PrP}(\mathrm{Sen})$ to $\operatorname{PrP}(\mathrm{Res})$ in vitro. J Mol Biol. 2003;332(1):47-57.

202. Deleault NR, Lucassen RW, Supattapone S. RNA molecules stimulate prion protein conversion. Nature. 2003;425(6959): 717-20.

203. Mabbott NA, Brown KL, Manson J, Bruce ME. T-lymphocyte activation and the cellular form of the prion protein. Immunology. 1997;92(2):161-5.

204. Bainbridge J, Walker KB. The normal cellular form of prion protein modulates T cell responses. Immunol Lett. 2005;96(1):147-50.

205. Cashman NR, Loertscher R, Nalbantoglu J, Shaw I, Kascsak RJ, Bolton DC, et al. Cellular isoform of the scrapie agent protein participates in lymphocyte activation. Cell. 1990;61(1):185-92.

206. Durig J, Giese A, Schulz-Schaeffer W, Rosenthal C, Schmucker U, Bieschke J, et al. Differential constitutive and activationdependent expression of prion protein in human peripheral blood leucocytes. Br J Haematol. 2000;108(3):488-95.

207. de Almeida CJ, Chiarini LB, da Silva JP, PM ES, Martins MA, Linden $\mathrm{R}$. The cellular prion protein modulates phagocytosis and inflammatory response. J Leukoc Biol. 2005;77(2):238-46.

208. Dodelet VC, Cashman NR. Prion protein expression in human leukocyte differentiation. Blood. 1998;91(5):1556-61. 
209.Zhang CC, Steele AD, Lindquist S, Lodish HF. Prion protein is expressed on long-term repopulating hematopoietic stem cells and is important for their self-renewal. Proc Natl Acad Sci USA. 2006;103(7):2184-9.

210. Hoshino S, Inoue K, Yokoyama T, Kobayashi S, Asakura T, Teramoto A, et al. Prions prevent brain damage after experimental brain injury: a preliminary report. Acta Neurochir Suppl. 2003;86:297-9.

211. McLennan NF, Brennan PM, McNeill A, Davies I, Fotheringham A, Rennison KA, et al. Prion protein accumulation and neuroprotection in hypoxic brain damage. Am J Pathol. 2004;165(1):227-35.

212. Weise J, Crome O, Sandau R, Schulz-Schaeffer W, Bahr M, Zerr I. Upregulation of cellular prion protein $(\mathrm{PrPc})$ after focal cerebral ischemia and influence of lesion severity. Neurosci Lett. 2004;372(1-2):146-50.

213. Marciano PG, Brettschneider J, Manduchi E, Davis JE, Eastman S, Raghupathi R, et al. Neuron-specific mRNA complexity responses during hippocampal apoptosis after traumatic brain injury. J Neurosci. 2004;24(12):2866-76.

214. Spudich A, Frigg R, Kilic E, Kilic U, Oesch B, Raeber A, et al. Aggravation of ischemic brain injury by prion protein deficiency: role of ERK-1/-2 and STAT-1. Neurobiol Dis. 2005;20(2):442-9.

215. Solforosi L, Criado JR, McGavern DB, Wirz S, Sanchez-Alavez M, Sugama $\mathrm{S}$, et al. Cross-linking cellular prion protein triggers neuronal apoptosis in vivo. Science. 2004;303(5663):1514-6.

216. Shyu WC, Kao MC, Chou WY, Hsu YD, Soong BW. Heat shock modulates prion protein expression in human NT-2 cells. Neuroreport. 2000;11(4):771-4.

217. Kuwahara C, Takeuchi AM, Nishimura T, Haraguchi K, Kubosaki A, Matsumoto Y, et al. Prions prevent neuronal cell-line death. Nature. 1999;400(6741):225-6.

218. Kim BH, Lee HG, Choi JK, Kim JI, Choi EK, Carp RI, et al. The cellular prion protein (PrPC) prevents apoptotic neuronal cell death and mitochondrial dysfunction induced by serum deprivation. Brain Res Mol Brain Res. 2004;124(1):40-50.

219. Kurschner C, Morgan JI. Analysis of interaction sites in homo- and heteromeric complexes containing Bcl-2 family members and the cellular prion protein. Brain Res Mol Brain Res. 1996;37 (1-2):249-58.

220. Bounhar Y, Zhang Y, Goodyer CG, LeBlanc A. Prion protein protects human neurons against Bax-mediated apoptosis. J Biol Chem. 2001;276(42):39145-9.

221. Roucou X, Giannopoulos PN, Zhang Y, Jodoin J, Goodyer CG, LeBlanc A. Cellular prion protein inhibits proapoptotic Bax conformational change in human neurons and in breast carcinoma MCF-7 cells. Cell Death Differ. 2005;12(7):783-95.

222. Li A, Harris DA. Mammalian prion protein suppresses Bax-induced cell death in yeast. J Biol Chem. 2005;280(17):17430-4.

223. Bounhar Y, Roucou X, LeBlanc AC. Prion protein prevents Baxmediated cell death in the absence of other Bcl-2 family members in Saccharomyces cerevisiae. FEMS Yeast Research. 2006;6(8):1204-12.

224. Diarra-Mehrpour M, Arrabal S, Jalil A, Pinson X, Gaudin C, Pietu $\mathrm{G}$, et al. Prion protein prevents human breast carcinoma cell line from tumor necrosis factor alpha-induced cell death. Cancer Res. 2004;64(2):719-27.

225. Bueler H, Fischer M, Lang Y, Bluethmann H, Lipp HP, DeArmond SJ, et al. Normal development and behaviour of mice lacking the neuronal cell-surface PrP protein. Nature. 1992;356(6370): $577-82$

226. Manson JC, Clarke AR, Hooper ML, Aitchison L, McConnell I, Hope J. 129/Ola mice carrying a null mutation in PrP that abolishes mRNA production are developmentally normal. Mol Neurobiol. 1994;8(2-3):121-7.

227. Bueler H, Raeber A, Sailer A, Fischer M, Aguzzi A, Weissmann C. High prion and PrPSc levels but delayed onset of disease in scrapie-inoculated mice heterozygous for a disrupted PrP gene. Mol Med. 1994;1(1):19-30.
228. Nishida N, Tremblay P, Sugimoto T, Shigematsu K, Shirabe S, Petromilli $\mathrm{C}$, et al. A mouse prion protein transgene rescues mice deficient for the prion protein gene from purkinje cell degeneration and demyelination. Lab Invest. 1999;79(6):689-97.

229. Brown DR, Nicholas RS, Canevari L. Lack of prion protein expression results in a neuronal phenotype sensitive to stress. J Neurosci Res. 2002;67(2):211-24.

230. Sakaguchi S, Katamine S, Nishida N, Moriuchi R, Shigematsu K, Sugimoto T, et al. Loss of cerebellar Purkinje cells in aged mice homozygous for a disrupted PrP gene. Nature. 1996; 380(6574):528-31

231. Moore RC, Lee IY, Silverman GL, Harrison PM, Strome R, Heinrich C, et al. Ataxia in prion protein ( $\mathrm{PrP})$-deficient mice is associated with upregulation of the novel PrP-like protein doppel. J Mol Biol. 1999;292(4):797-817.

232. Moore RC, Mastrangelo P, Bouzamondo E, Heinrich C, Legname $\mathrm{G}$, Prusiner SB, et al. Doppel-induced cerebellar degeneration in transgenic mice. Proc Natl Acad Sci USA. 2001;98(26): 15288-93.

233. Flechsig E, Hegyi I, Leimeroth R, Zuniga A, Rossi D, Cozzio A, et al. Expression of truncated PrP targeted to Purkinje cells of PrP knockout mice causes Purkinje cell death and ataxia. EMBO J. 2003;22(12):3095-101.

234.Scott M, Foster D, Mirenda C, Serban D, Coufal F, Walchli M, et al. Transgenic mice expressing hamster prion protein produce species-specific scrapie infectivity and amyloid plaques. Cell. 1989;59(5):847-57.

235.Prusiner SB, Scott M, Foster D, Pan KM, Groth D, Mirenda C, et al. Transgenetic studies implicate interactions between homologous PrP isoforms in scrapie prion replication. Cell. 1990;63(4): 673-86.

236. Telling GC. Prion protein genes and prion diseases: studies in transgenic mice. Neuropathol Appl Neurobiol. 2000;26(3): 209-20.

237. Westaway D, DeArmond SJ, Cayetano-Canlas J, Groth D, Foster D, Yang SL, et al. Degeneration of skeletal muscle, peripheral nerves, and the central nervous system in transgenic mice overexpressing wild-type prion proteins. Cell. 1994;76(1): 117-29.

238. Paitel E, Alves da Costa C, Vilette D, Grassi J, Checler F. Overexpression of PrPc triggers caspase 3 activation: potentiation by proteasome inhibitors and blockade by anti-PrP antibodies. J Neurochem. 2002;83(5):1208-14.

239. Tateishi J, Kitamoto T, Hoque MZ, Furukawa H. Experimental transmission of Creutzfeldt-Jakob disease and related diseases to rodents. Neurology. 1996;46(2):532-7.

240. Hsiao K, Scott M, Foster D, DeArmond SJ, Groth D, Serban H, et al. Spontaneous neurodegeneration in transgenic mice with prion protein codon 101 proline----leucine substitution. Ann N Y Acad Sci. 1991;640:166-70.

241. Shmerling D, Hegyi I, Fischer M, Blattler T, Brandner S, Gotz J, et al. Expression of amino-terminally truncated PrP in the mouse leading to ataxia and specific cerebellar lesions. Cell. 1998;93(2):203-14.

242. Cohen E, Taraboulos A. Scrapie-like prion protein accumulates in aggresomes of cyclosporin A-treated cells. EMBO J. 2003; 22(3):404-17.

243. Roucou X, Gains M, LeBlanc AC. Neuroprotective functions of prion protein. J Neurosci Res. 2004;75(2):153-61.

244.Zuscik MJ, Sands S, Ross SA, Waugh DJ, Gaivin RJ, Morilak D, et al. Overexpression of the alpha1B-adrenergic receptor causes apoptotic neurodegeneration: multiple system atrophy. Nat Med. 2000;6(12):1388-94

245.Robertson J, Kriz J, Nguyen MD, Julien JP. Pathways to motor neuron degeneration in transgenic mouse models. Biochimie. 2002;84(11):1151-60

246.Festoff BW, D'Andrea MR, Citron BA, Salcedo RM, Smirnova IV, Andrade-Gordon P. Motor neuron cell death in wobbler mutant mice follows overexpression of the G-protein-coupled, proteaseactivated receptor for thrombin. Mol Med. 2000;6(5):410-29. 
247.Shmerling D, Hegyi I, Fischer M, Blattler T, Brandner S, Gotz J, et al. Expression of amino-terminally truncated PrP in the mouse leading to ataxia and specific cerebellar lesions. Cell. 1998; 93(2):203-14.

248.Hegde R, Mastrianni J, Scott M, Defea K, Tremblay P, Torchia M, et al. A transmembrane form of the prion protein in neurodegenerative diseases. Science. 1998;279:827-34.

249.Hsiao K, Scott M, Foster D, DeArmond SJ, Groth D, Serban H, et al. Spontaneous neurodegeneration in transgenic mice with prion protein codon 101 proline----leucine substitution. Ann N Y Acad Sci. 1991;640(166):166-70.

250.Walmsley AR, Zeng F, Hooper NM. Membrane topology influences $\mathrm{N}$-glycosylation of the prion protein. Zuscik MJ, Sands S, Ross SA J. 2001;20(4):703-12.
251.Zanusso G, Petersen RB, Jin T, Jing Y, Kanoush R, Ferrari S, et al. Proteasomal degradation and N-terminal protease resistance of the codon 145 mutant prion protein. J Biol Chem. 1999; 274(33):23396-404.

252.Hay B, Barry RA, Lieberburg I, Prusiner SB, Lingappa VR. Biogenesis and transmembrane orientation of the cellular isoform of the scrapie prion protein erratum in: Mol Cell Biol. 1987; May 7(5):2035. Mol Cell Biol. 1987; 7(2):914-20.

253.Lopez CD, Yost CS, Prusiner SB, Myers RM, Lingappa VR. Unusual topogenic sequence directs prion protein biogenesis. Science. 1990;248(4952):226-9. 